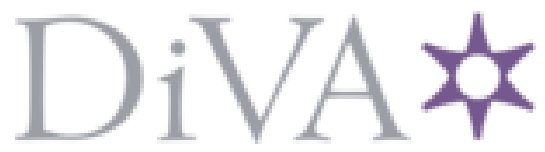

http://www.diva-portal.org

This is the published version of a chapter published in Receptions of Paul in Early Christianity: The Person of Paul and His Writings through the Eyes of His Early Interpreters.

Citation for the original published chapter:

Kelhoffer, J A. (2018)

The Ecclesiology of 2 Clement 14: Ephesians, Pauline Reception, and the Church's Preexistence

In: Edited by Simon Butticaz, Andreas Dettwiler, and Jens Schröter, in cooperation with Clarissa Paul (ed.), Receptions of Paul in Early Christianity: The Person of Paul and His Writings through the Eyes of His Early Interpreters (pp. 377-409). Berlin:

Walter de Gruyter

Beihefte zur Zeitschrift für die neutestamentliche Wissenschaft https://doi.org/10.1515/9783110533781-015

N.B. When citing this work, cite the original published chapter.

Permanent link to this version:

http://urn.kb.se/resolve?urn=urn:nbn:se:uu:diva-404165 


\title{
The Ecclesiology of 2 Clement 14
}

\section{Ephesians, Pauline Reception, and the Church's Preexistence}

\begin{abstract}
This study concurs with Andrew Gregory, Paul Foster, and other scholars on the unlikelihood that a positive case for a direct literary relationship between Ephesians and Second Clement can be made. It is also affirmed that John Muddiman makes a valuable methodological suggestion that, when weighing the relative probability of a literary relationship, similarities between two writings in addition to exact verbal agreement can, and arguably should, be taken into consideration. Concerning the preexistent church in 2 Clement 14, there are numerous reasons to infer that either Ephesians or a very similar apostolically ascribed writing informed Clement's ecclesiology. In interpreting Ephesians, Second Clement may also be correcting its soteriology: instead of positing a predestined elect who have already been raised and seated with Christ (Eph 1:3-5; 2:6), Clement warns about the dangers of corrupting the flesh (14:3-5), hoping that his flock will be prepared for the final judgment (cf. 17:3-7). According to Clement, only those who keep the flesh pure will have hope of belonging to "the first, spiritual church" (14:1) and, as part of that church, of being reunited with Christ, with whom the church existed in the beginning (14:2).
\end{abstract}

Keywords: Body of Christ, Colossians, Ecclesiology, Ephesians, Preexistence, Second Clement.

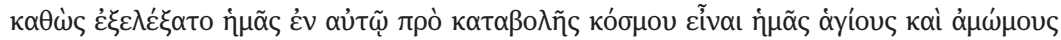

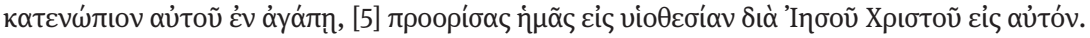

(Eph 1:4-5a)

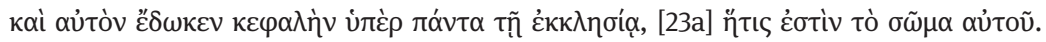

(Eph 1:22b-23a)

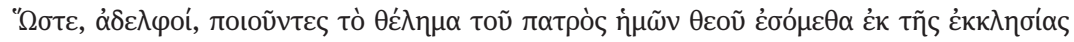

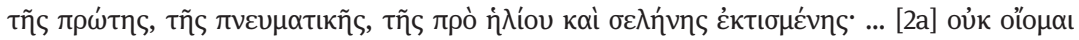

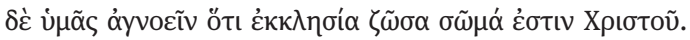

(2 Clem. 14:1a, 2a) 


\section{Introduction}

Chapters 12 and 14 of the remarkably misnamed Second Epistle of Clement to the Corinthians ${ }^{1}$ are commonly interpreted as the work's most "gnostic" and/or "antignostic" sections. They are, in any case, among its most bewildering passages. 2 Clem. 12:2b cites an unusual saying of the Lord about androgynous thinking and eschatology, ${ }^{2}$ and 14:2a holds that Gen 1:27 ("God made humankind masculine and feminine") refers to Christ as the masculine part and to the church as the feminine part of the primordial ôv $\theta \rho \omega \pi$ \% . The identification in 2 Clem. 14:2a of "the living church" as "the body of Christ" invites an investigation of possible Pauline reception by, or influence on, Clement. ${ }^{3}$ In an earlier study, I have critically evaluated whether anti-Gnosticism can be detected in 2 Clement $12-13 .{ }^{4}$ The question this investigation takes up is, can distinctively Pauline or gnostic influences be detected in 2 Clement 14, and how might those influences shed light on the author's ecclesiology?

Second Clement claims that the church ( with Christ prior to the creation of the cosmos (14:1-2). Some scholars hold that Ephesians likewise affirms the preexistence of the church. This study examines the concept of church in these two early Christian writings relative to other ecclesiologies in the NT Pauline letters. The question whether Ephesians influ-

1 The anonymous author has no clear connection to First Clement or to any other person named "Clement"; the writing lacks epistolary features; and there is no obvious connection with Corinth.

2 According to 2 Clem. 12:2b, the Lord's kingdom will come "whenever the two will be one, and what is outside corresponds to what is inside, and what is male with the female, neither male nor female."

3 For the sake of convenience, I refer to this anonymous, and otherwise unknown, author as "Clement" without making any claim about the author's identity.

4 James A. Kelhoffer, "Eschatology, Androgynous Thinking, Encratism, and the Question of Anti-Gnosticism in 2 Clement 12," a two-part study forthcoming in Vigiliae Christianae. Part One problematizes the widespread use of an untenably broad definition of Gnosticism to support claims that 2 Clement 12 is antignostic. Several conclusions about the writing's aims and opponents must therefore be reconsidered. Part Two completes the analysis of 2 Clement 12 and examines 2 Clement 13, an analysis which casts further doubt upon the notion that 12:5-6 calls for sexual renunciation. It is argued that 12:1-13:4 is not polemical and does not censure any distinctively gnostic views or praxes. By shedding both the supposedly gnostic background of the dominical logion (12:2b, 6b) and an antignostic agenda for the interpretations of the logion (12:3-5), scholarship has a better chance of opening up promising avenues for interpreting 12:1-13:4. In particular, the call to cultivate thinking that does not take into account a Christian's gender (12:5) and the notion that the kingdom's arrival depends on believers' moral development (12:6) merit further investigation. 
enced Second Clement and the possibility of both writings' indebtedness to the Corpus Paulinum will also be considered.

It is argued that whereas Ephesians does not seem to envision a preexistent church, Second Clement clearly does. However, a direct literary relationship between Ephesians and Second Clement probably cannot be demonstrated. Nevertheless, several elements in Ephesians could well have influenced Second Clement, perhaps indirectly. An exploration of key terms as well as motifs in each writing supports the inference, however tentative, that parts of 2 Clement 14 are ultimately indebted to Ephesians or to a very similar writing. In future research, examination of additional ancient cosmogonies could shed additional light on the passage, especially if any comparisons drawn were not tainted by an outdated concept of "Gnosticism."

Second Clement refers vaguely to two authorities, "the books and the apostles," that are said to support the teaching that "the church [exists] not [only] now but [also] from the beginning." 5 The text leaves unspecified the "books" and "apostles" upon which this particular - and rather distinctive - teaching is based. A number of explanations could account for the author's vagueness about these posited authorities. Does Clement refer to writings known to him but that do not survive? Or, does he refer to writings that do survive but whose teaching he summarizes loosely or whose wording he may recall somewhat incorrectly? Further, might he obliquely refer to esteemed traditions with which he only partially agrees? In any of those scenarios, it could be very difficult to identify the writings or authorities to which he refers. Another possibility is that he bases a teaching on contrived authorities that did not actually exist. ${ }^{6}$ With good reason, scholarship commonly labels Clement as a prooftexter who attaches surprising, arbitrary, and even, at times, incoherent interpretations to the authoritative materials he cites. ${ }^{7}$ One purpose of this essay is to suggest how Ephesians or some similarly apostolically ascribed material could have inspired parts of 2 Clement 14.

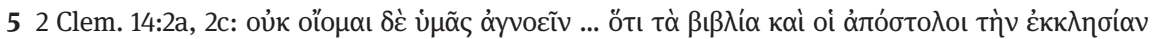

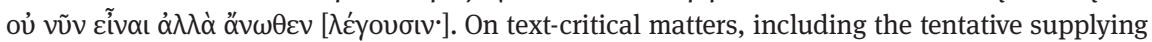
of $\left[\lambda \varepsilon^{\prime} y o v \sigma ı\right]$ to this possible anacoluthon, see the discussion, below.

6 Such a possibility, while probably not provable, could nonetheless be weighed if the aforementioned options were shown to be untenable.

7 See, e.g., James A. Kelhoffer, "Pigeonholing a Prooftexter? The Citations in 2 Clement 2 and Their Alleged ‘Gnostic’ Background,” ZNW 107/2 (2016): 266-295 esp. 267-268, 270-272. 


\section{Prolegomena}

In the 2005 volume The Reception of the New Testament in the Apostolic Fathers, the editors Andrew F. Gregory and Christopher M. Tuckett devote an entire chapter to theoretical considerations, methodology, and criteria for ascertaining literary dependence. ${ }^{8}$ Several particularities about Ephesians and Second Clement merit attention before we proceed.

One limitation in applying any set of criteria for determining possible literary dependence arises from the inability to produce certainty of results. In early Christian literature, we have (almost) no example of an author borrowing from an esteemed written tradition without also altering that tradition, sometimes markedly. As a result, if more or less exact reproduction of an earlier text were the standard, literary dependence would be all but impossible to demonstrate, even when there are clear points of contact between two writings. Nevertheless, a positive case for direct borrowing can be compelling if a writing contains redactional markers or particularly distinctive terms that are prominent in another writing. In the absence of such conclusive proof, the options include attributing similarities to an earlier, common (but to us lost) written tradition, to a common oral tradition, or to indirect borrowing. Another possibility that we will suggest in this study is that literary dependence may be inferred as the most like$l y$, albeit not a demonstrable, explanation.

The two writings on which this paper focuses - Ephesians and Second Clement - could well be roughly contemporaneous. Although it is not entirely certain which of them was written first, we adopt as a working hypothesis that Ephesians predates Second Clement. ${ }^{9}$ For this study, it is relevant that Colossians is most likely a deutero-Pauline letter ${ }^{10}$ ostensibly addressed to the Christ-believing

8 Andrew Gregory and Christopher Tuckett, "Reflections on Method. What Constitutes the Use of the Writings That Later Formed the New Testament in the Apostolic Fathers?" in The Reception of the New Testament in the Apostolic Fathers (ed. Andrew Gregory and Christopher Tuckett; Oxford: Oxford University, 2005), 61-82.

9 Traditionally, scholarship has tended to assume that, if any influence is to be detected, the canonical writing (Ephesians) influenced the extracanonical writing (Second Clement). Most exegetes nowadays, however, have abandoned the problematic distinction between "apostolic" and "subapostolic" writings, since several of the later NT writings date to the same period as do several of the Apostolic Fathers.

10 On the authorship of Colossians, see, e. g., Helmut Koester, History and Literature of Early Christianity (vol. 2 of Introduction to the New Testament; 2nd ed.; Philadelphia: Fortress, 1982 [1980]), 2:263-267; Victor Paul Furnish, “Colossians, Epistle to the," ABD 1:1090-1096, esp. 1092-1094; Udo Schnelle, The History and Theology of the New Testament Writings (Minneapolis: Fortress, 1998 [2nd German ed. 1994]), 282-288; Bart D. Ehrman, Forgery and Counterfor- 
congregation in Colossae, and was probably written at some point after the earthquake that struck nearby Laodicea in 60/61 CE, perhaps around 70-90 CE. ${ }^{11}$ It is also relevant that, as scholarship generally acknowledges, Ephesians is a deutero-Pauline letter ${ }^{12}$ that reworks significant portions of Colossians. ${ }^{13}$ As a result, Ephesians is two steps removed from the apostle Paul, and the date of Ephesians (ca. 80-110 CE?) is quite uncertain. ${ }^{14}$

The date of Second Clement is even more uncertain. Meager evidence undergirds the widespread - but likely correct - view that Second Clement was probably written between $c a .125$ and $c a$. 170 CE (with most scholars opting for ca. 150

gery. The Use of Literary Deceit in Early Christian Polemics (New York: Oxford University Press, 2013), 171-182.

11 Tacitus, Ann. 14.27.1. This inference is based on the likelihood that Colossae (roughly $18 \mathrm{~km}$ southeast of Laodicea) was also destroyed or severely damaged by that earthquake, which would be relevant for dating Colossians and for the possibly fictitious characterization of the addressees by its pseudonymous author. Colossae may have been an unquestionable destination posited for a pseudonymous letter, since after the earthquake there may not have been any or, in any case, many Christ-believers from Colossae or Laodicea who could have questioned the authenticity of such an allegedly earlier apostolic letter. See, further, James A. Kelhoffer, “The Relevance of Revelation's Date and the Imperial Cult for John's Appraisal of the Value of Christians' Suffering in Revelation 1-3" (2012), in idem, Conceptions of "Gospel” and Legitimacy in Early Christianity (WUNT 324; Tübingen: Mohr Siebeck, 2014), 233-265 at 234-237; James S. Murray, “The Urban Earthquake Imagery and Divine Judgement in John's Apocalypse," NovT 47 (2005): 142-161, esp. 150 - 158 at 157; Richard Bauckham, "Eschatological Earthquake in the Apocalypse of John,” NovT 19 (1977): 224-233; David Lincicum, “Mirror-Reading a Pseudepigraphal Letter,” NovT 59/2 (2017): 171-193, taking Colossians as an example of the need to examine pseudepigraphal letters more as rhetorical compositions than as epistolary literature that reflect the actual historical situation posited in the letter.

12 On the non-Pauline authorship of Ephesians, see, e.g., Koester, Introduction (see n. 10), 2:267-272; Victor Paul Furnish, "Ephesians, Epistle to the," $A B D$ 2:535-542, esp. 539-541; Schnelle, History and Theology (see n. 10), 300 - 303; Nils A. Dahl, "Einleitungsfragen zum Epheserbrief," in idem, Studies in Ephesians (ed. David Hellholm, Vermund Blomkvist, and Tord Fornberg; WUNT 131; Tübingen: Mohr Siebeck, 2000), 3-105, esp. 18-28, 48-60; Ehrman, Forgery and Counterforgery (see n. 10), 182-190.

13 In regard to the reuse of significant parts of Colossians in Ephesians, see Furnish, "Ephesians" (see n. 12), 536-537, Dahl, "Einleitungsfragen" (see n. 12), 39-48, and the other studies listed in the preceding footnote.

14 On the uncertainties about the date of Ephesians, see, e.g., John Muddiman, A Commentary on the Epistle to the Ephesians (BNTC; London: Continuum, 2001), 34-36; cf. 41-47; idem, "The Church in Ephesians, 2 Clement, and the Shepherd of Hermas," in Trajectories through the New Testament and the Apostolic Fathers (ed. Andrew Gregory and Christopher Tuckett; Oxford: Oxford University, 2005), 107-121 at 109-110. A terminus ante quem for Ephesians is likely set by the allusions to Eph 1:3-14 in Ign. Eph. Prologue; 12:2. 
CE) ${ }^{15}$ A key point of relative chronology is that, as C. M. Tuckett has argued, "the tradition on which 2 Clement is based for its knowledge of Jesus tradition represents a stage which presupposes the finished gospels of both Matthew and Luke."16 The inference that Second Clement postdates the Synoptic Gospels is based on the recognition of Matthean and Lukan redaction in several sayings of Jesus that Second Clement cites. ${ }^{17}$ That observation suggests that Second Clement was written after ca. $100 \mathrm{CE}$ and probably after ca. 125. A terminus ante quem for the writing is difficult to ascertain, however.

A final prolegomenon concerns the analysis of Second Clement in relation to “Gnosticism.” Holt L. Graham's comparison of the use of Ephesians in 2 Clement 14 to the "imaginative exegesis like that of the Gnostics"18 is based on a misconception common in numerous studies of Second Clement. A categorization of Gnostic "reverse" or "protest exegesis" was not unusual when Graham wrote in the 1960s but has, in more recent scholarship, been shown to be imprecise and unhelpful. ${ }^{19}$ Further, conclusions about the gnostic opponents and gnostic influences in Second Clement, although a recurring refrain in generations of secondary literature, have recently been challenged. ${ }^{20}$ One reason for re-evaluating the scholarly consensus of gnostic influence stems from problems shown in earlier scholarship's generalizations about Gnosticism and about purported unify-

15 Ernst Baasland, "Der 2. Klemensbrief und frühchristliche Rhetorik: 'Die erste christliche Predigt' im Lichte der neueren Forschung," in ANRW II.27.1 (Berlin: de Gruyter, 1993): 78-157, esp. 88-89 at 88, notes, "Bei kaum einer frühchristlichen Schrift ist die Unsicherheit" about the date of composition "so groß wie beim 2. Klem.” Likewise, Christopher Tuckett, 2 Clement: Introduction, Text, and Commentary (Oxford Apostolic Fathers; Oxford: Oxford University, 2012), 62-64 at 64, describes the evidence apropos dating as "very flimsy" and cautiously suggests "some stage in the early-middle 2nd century."

16 Andrew F. Gregory and Christopher M. Tuckett, "2 Clement and the Writings That Later Formed the New Testament," in Reception of the New Testament (see n. 8), 251-292 at 277 [hereafter: Gregory, "2 Clement and the Writings"]. See, further, ibid., 254-276 and the oftentimes more detailed discussions in Tuckett, 2 Clement (see n. 15).

17 The ultimate origin of those sayings is open to debate and cannot be addressed in this essay. At least three explanations are possible: Clement could have cited those two Gospels individually, a harmonized gospel source, or some other intermediate source that drew on Matthew and Luke, possibly combining elements of both Gospels prior to their use in Second Clement.

18 Robert M. Grant and Holt L. Graham, First and Second Clement (The Apostolic Fathers 2; New York: Nelson, 1965), 126 [hereafter: Graham, Second Clement].

19 See, e.g., Michael A. Williams, Rethinking “Gnosticism": An Argument for Dismantling a Dubious Category (Princeton: Princeton University, 1996), 54-79, esp. 60-62. We return to this point toward the end of this essay.

20 See Tuckett, 2 Clement (see n. 15), esp. 47-57; James A. Kelhoffer, "Second Clement and Gnosticism. The status quaestionis,” EC 8/1 (2017): 124-149. 
ing features of gnostic literature. Another objection to characterizing the author of Second Clement as antignostic is the lack of clear polemic in the writing against any distinctively gnostic belief or practice. ${ }^{21}$ Henceforth, any study of Pauline reception by Clement or any other early Christian author that would posit the indirect influence of Ephesians filtered through generalizations about the eccentric character of gnostic exegesis of sacred texts will be met with skepticism: the presuppositions are untenable and limited in their explanatory power.

Quo vademus? In all honesty, I must acknowledge that the way forward is not entirely clear. The removal of presuppositions about the priority and influence of canonical NT texts and about the random and sometimes incoherent gnostic interpretations of sacred texts could increase the complexity of undertaking a study like this one. Such difficulties are by no means unique to an examination of Ephesians or Second Clement and could be relevant for several of the papers from the symposia in Lausanne and Berlin that are published in this volume. The recognition of such difficulties not only helps us to understand the limitations of earlier paradigms but can also open up new possibilities for a fresh analysis of the evidence.

\section{Conceptions of Ecclesiology in the Corpus Paulinum}

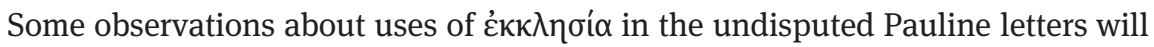
serve as a basis for comparisons of those letters with Colossians, Ephesians, and Second Clement. Attention will also be given to the Pauline metaphor of how Christ-believers, collectively, are Christ's "body" $(\sigma \tilde{\omega} \mu \alpha)$. In early Christian literature, that metaphor is distinctive to certain undisputed letters, Colossians, Ephesians, and Second Clement. We will see how in 2 Clement 14 the occurrences of $\varepsilon \kappa \kappa \lambda \eta \sigma i ́ \alpha$ in the singular referring to the whole church, as well as the reference

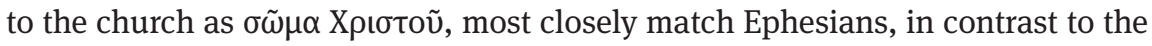
undisputed letters and Colossians. As a result, if any part of the Corpus Paulinum influenced Clement, the most likely candidate for that influence would be Ephesians.

21 In my view, it would be highly implausible to infer that Clement criticized Gnostics, not because anything those opponents professed or did was "gnostic" or was somehow incompatible with purportedly proto-orthodox views. See the aforementioned studies by Tuckett (see n. 20) and Kelhoffer (see n. 20). 


\subsection{The Undisputed Letters}

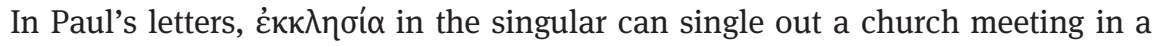
particular house or the Christ-groups in a particular city. ${ }^{22}$ Oftentimes, the apos-

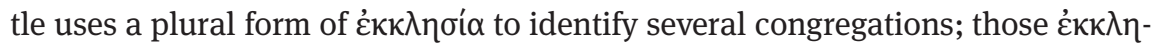
oíal can be of a particular region, ${ }^{23}$ can refer to some congregations in contrast to others, ${ }^{24}$ or can designate assemblies of the church as a whole. ${ }^{25}$ Exceptionally, a singular form of $\varepsilon \kappa \kappa \lambda \eta \sigma i ́ \alpha$ can refer to the church in general, albeit not to the

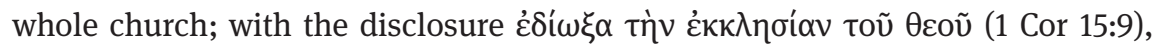
Paul does not claim that he persecuted the entire church, much less each and every congregation.

In his vision of a "spiritual church that was created before the sun and moon" (2 Clem. 14:1), Clement does not draw on a concept traceable to any of the undisputed Pauline letters. The closest analogy to such a concept in Paul's surviving letters would be the allegory of Hagar (Gal 4:21-31), in which the free woman (Sarah) corresponds to "the Jerusalem above." According to Paul's interpretation of Genesis 16 and 21, "the present Jerusalem” is descended from Hagar, and "the Jerusalem above" from Sarah (Gal 4:25-26). His salvation-historical reference in Galatians postdates Abraham as the first believer (Gal 3:6-7; cf. Rom 4:3) and posits a demarcation between the respective heirs of Sarah and Hagar. The existence of the present and the transcendent Jerusalem is thereby traced as far back as the families that Abraham started with Sarah and Hagar, since which time there have been "two covenants" (Gal 4:24). ${ }^{26}$ In Romans 5, Paul points to the origin of sin at an even earlier time, namely the transgression of Adam in Genesis 3, but Paul's focus there is anthropological rather than ecclesiological. ${ }^{27}$ Compared with Gal 4:21-31 (and Romans 5), the point

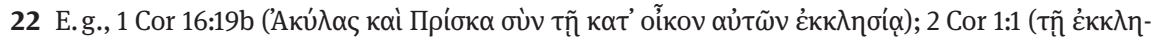

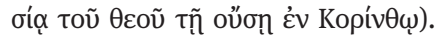

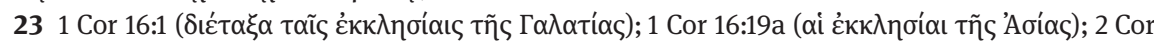

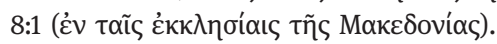

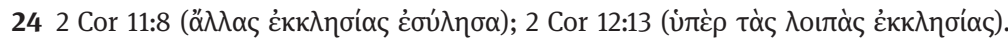

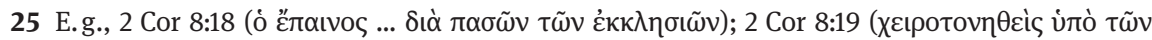

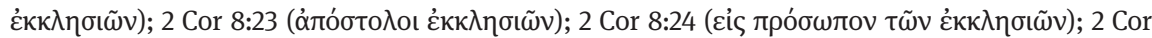

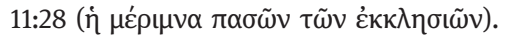

26 Muddiman, "Church" (see n. 14), 112, seems to overreach when identifying "the "pre-existence' of the redeemed community being made clear in the allegory of Sarah" (Gal 4:26).

27 See, further, James A. Kelhoffer, "The Struggle to Define Heilsgeschichte. Paul on the Origins of the Christian Tradition," in idem, Conceptions of "Gospel" and Legitimacy (see n. 11), 97-120, esp. 107-114. Paul focuses mostly on Adam in Romans 5, where Eve would presumably clutter up his бúyкрıбı with Christ (pace 1 Tim 2:13-15). 
in time envisioned in 2 Clem. 14:1 prior to the creation of the material world is even earlier. Thus, such an understanding of the church's preexistence cannot be attributed to any of the undisputed Pauline letters.

\subsection{The Church as "Body"}

The church as Christ's "body" is a distinctively Pauline metaphor. ${ }^{28}$ A brief overview of this metaphor in the Pauline letters will facilitate an evaluation of wheth-

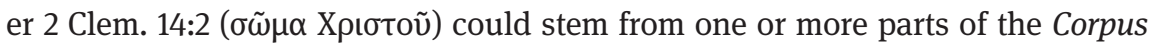
Paulinum. We will hold that the closest correspondences to 2 Clem. 14:2 occur in the letters of Colossians and Ephesians, correspondences that suggest the possibility of some deutero-Pauline influence on Clement.

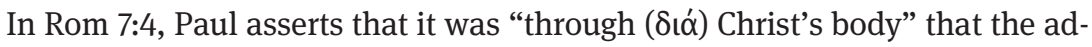
dressees "were put to death through the law."29 Just how Paul conceptualizes "Christ's body" and its role in believers' previous spiritual or existential death is not clear, however. ${ }^{30}$ Later in the same letter, Paul states that all believers comprise "one body in Christ." 31 To the Corinthians he asserts that their bodies are

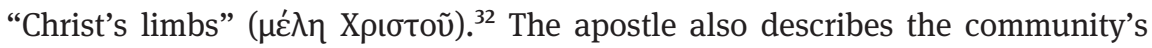
shared "bread" as "a participation in Christ's body." 33

Paul's most extensive use of the body of Christ metaphor is in 1 Cor 12:12-31. His primary concern seems to be that equal honor should be apportioned to all the body's “members," or "limbs” ( $\left.\mu \varepsilon^{\prime} \lambda \eta\right)$, regardless of their ethnicity (12:13), their function within the community $(12: 15-17,21)$, or their perceived position of strength or weakness (12:22-24a). The particular arrangement of the one body is ascribed to God's handiwork $(12: 18,24 b-25,28)$ and could be construed as emblematic of God's continuous activity as creator who is forming a new humanity that comprises one body in Christ. Because the Corinthians, along with

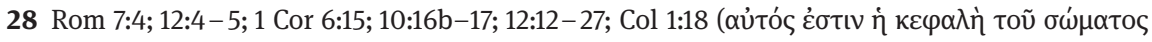

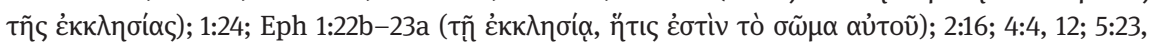
30.

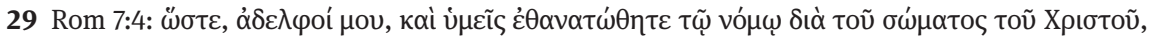

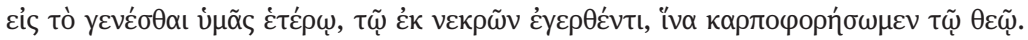

30 On the linking of baptism with death in Romans 6 and Mark 10, see Bim O'Reilly, "Baptism and Death. A Study of Mark and Romans” (Th.D. diss., Uppsala University, 2017).

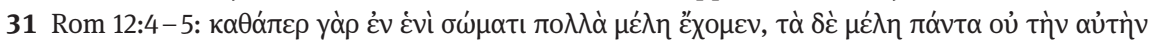

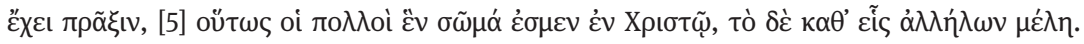

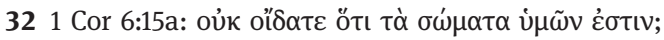

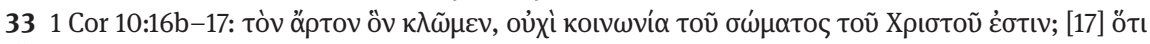

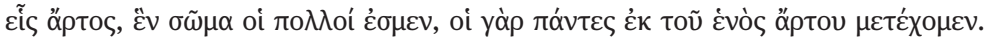




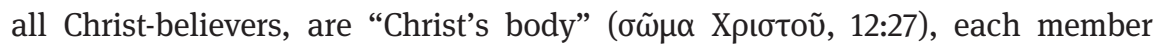
must respect the role of, and care for the well-being of, the other members (12:25-26, 29-31).

In the NT writings, $\sigma \tilde{\omega} \mu \alpha$ occurs with Xpıбтó only in certain Pauline letters as a metaphor for the collective community of Christ-believers, ${ }^{34}$ which underscores the distinctiveness of this brief Pauline idiom. In the Apostolic Fathers, the only such occurrence of $\sigma \tilde{\omega} \mu \alpha$ with Xpıбтó is 2 Clem. 14:2. ${ }^{35}$ Although the

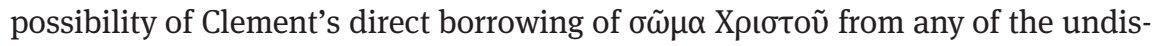
puted letters cannot be excluded, it would be very difficult to demonstrate a direct source for just these two words, since no part of 2 Clement 14 reflects any of Paul's particular concerns about an earlier death experienced by believers (cf. Rom 7:4), the unity of the one body (cf. Rom 12:4-5), or the identity and role of Christ-believers as "limbs" ( $\left.\mu \varepsilon^{\prime} \lambda \eta\right)$ of the body who must care for one another (Rom 12:4-5; 1 Cor 6:15a; 12:12, 25-27). Moreover, the undisputed Pauline letters never specify an equivalence between Christ's $\sigma \tilde{\omega} \mu \alpha$ and the $\varepsilon \kappa \kappa \lambda \eta \sigma i \alpha$. As is discussed below, that innovation should probably be credited to the author of Colossians, whose novelty is reflected also in Ephesians.

\subsection{The Ecclesiology of Colossians}

The author of Colossians intriguingly extends the Pauline metaphor that we have just surveyed: the "body" is now said to have a "head" ( $\varepsilon \varphi \alpha \lambda \eta$ '), namely Christ

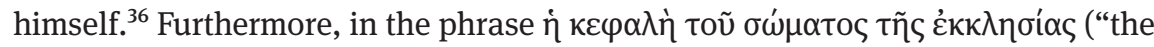
head of the body, [namely] the church," Col 1:18) the appositional genitive identifies the "church" with the immediately aforementioned "body." Similarly, Col

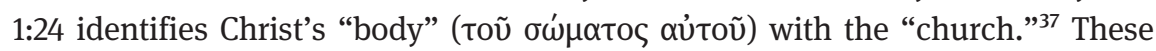

34 By contrast, the author of Hebrews refers to Jesus Christ's "body" $(\sigma \tilde{\omega} \mu \alpha)$ not in an ecclesio-

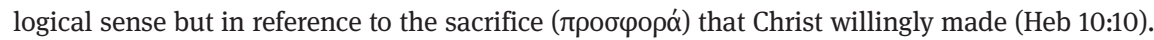

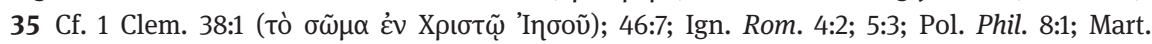
Pol. 14:2; 17:2; 19:2, where $\sigma \tilde{\omega} \mu \alpha$ and Xpıбтó occur in the same verse but not in reference to "Christ's body."

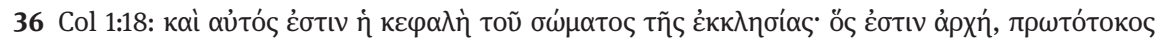

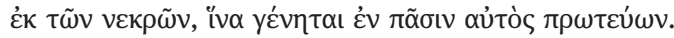

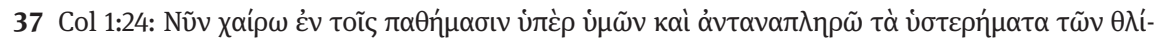

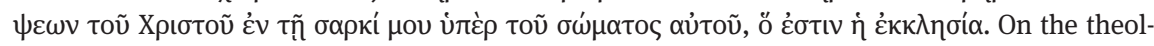
ogy of suffering in Col 1:24 and the remarkable comparison drawn between Paul's "sufferings" and Christ's "tribulations," see James A. Kelhoffer, Persecution, Persuasion and Power. Readiness to Withstand Hardship as a Corroboration of Legitimacy in the New Testament (WUNT 270; Tübingen: Mohr Siebeck, 2010), 70 - 78. 


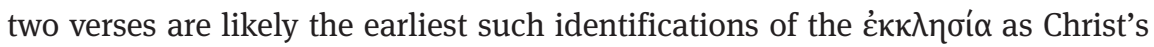
body and could have been a precedent for the author of Second Clement.

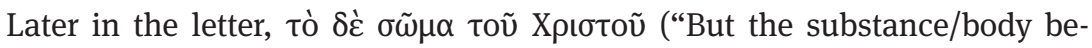
longs to Christ," Col 2:17) uses familiar Pauline terms but does not seem to build on the Pauline metaphor that believers, together, comprise Christ's body. Elsewhere in Colossians, the affirmation that believers "were called in one body" 38 expresses a sentiment fully consistent with the ecclesiology and "body" language in 1 Corinthians 12. Likewise, toward the end of the letter the instruction to greet a house church (Col 4:15; cf. 1 Cor 16:19b) and the reference to the church in another city (Col 4:16; cf. 2 Cor 1:1) match expressions noted above in the undisputed letters. ${ }^{39}$

We have seen that the identification of the church as Christ's body, which is assumed in 2 Clem. 14:2, is likewise assumed in Colossians. Although possible, it remains uncertain whether this letter may have influenced Clement. In that letter, the gestalt of Paul is said to suffer "in place of" (ن்rép, Col 1:24) the church, ${ }^{40}$ which is a fascinating view of the apostle's vicarious suffering for the church and is not attested elsewhere in the Corpus Paulinum or in the Apostolic Fathers, including Second Clement..$^{41}$ Nonetheless, Col 1:15-18 could have encouraged the ecclesiological line of thinking in 2 Clement 14: if Christ existed before the world was created, and if his body is the church, then it could follow that the church was (and still is) Christ's celestial body. Of course, this is not what the author of Colossians says, but a later author like Clement could have taken such sentiments as a point of departure. As we shall see, the ecclesiological reflection of Colossians is developed further in Ephesians, a writing that in certain respects is conceptually closer to 2 Clement 14 than are the undisputed letters and Colossians.

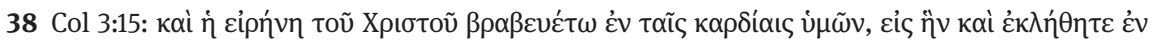

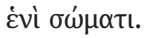

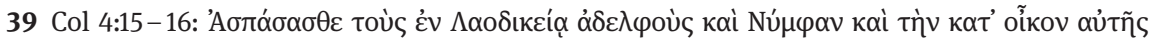

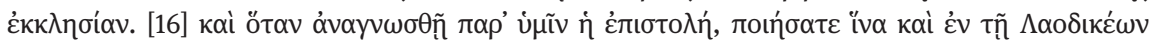

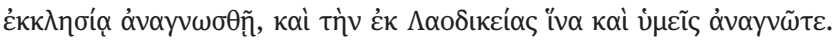

40 See Kelhoffer, Persecution, Persuasion and Power (see n. 37), 75-77.

41 Contrast 2 Clem. 11:4, which posits that the Lord's "people" have had "turmoils and tribula-

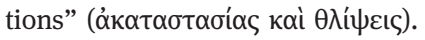




\subsection{The Ecclesiology of Ephesians}

Among the NT Pauline letters, a distinctive feature of Ephesians is the likelihood that the letter did not originally present itself as a missive to a particular city or congregation but was a general address to all "the saints and faithful ones" (1:1b) who would read or hear its message. ${ }^{42} \mathrm{~A}$ central theme is the unity of the one church made up of Jews and Gentiles. The positing of a general readership and the writing's focus on the church at large correlate with its nine occurrences

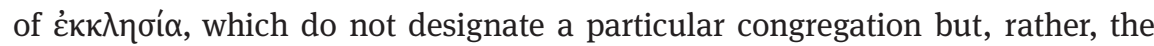
church as a whole. ${ }^{43}$

As John Muddiman notes, a distinctive aspect of Ephesians's ecclesiology is the notion that believers were elected in Christ before the foundation of the world. ${ }^{44}$ Ephesians is apparently the first early Christian writing to make such a claim about the antediluvian existence of Christ-believers. ${ }^{45}$ Although the

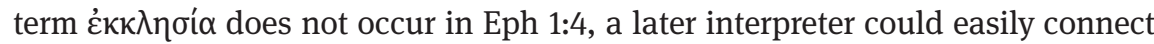
the dots between, on the one hand, the existence of those chosen in Christ prior to creation and, on the other hand, inferring the church's existence at that time. Thus, in Ephesians the church's preexistence may be implicit but is not explicit. Another peculiarity of the writing's ecclesiology, partly derived from Colossians, is the assertion that believers are not only raised with Christ (cf. Col 2:12; 3:1) but also seated with him in heaven (Eph 2:6). ${ }^{46}$

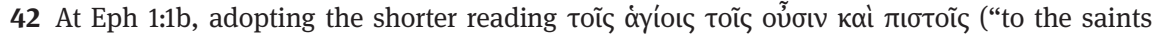
who are also the faithful ones," attested in $\aleph$ A F G K L $\Psi$ 81. 104. 365. 630. 1175. 1241. 1739.

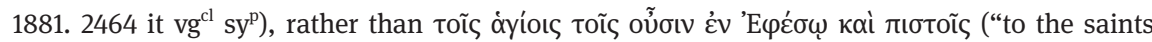
who are in Ephesus and [are] faithful," attested in $\mathrm{P}^{46}$ B D P 0278.33.1505 b vg ${ }^{\text {st.ww }}$ sy $^{\mathrm{h}}$ ). See also the essay by Christine Gerber, "Paulus als Ökumeniker. Die Interpretation der paulinischen Theologie durch den Epheserbrief," 317-354 in this volume.

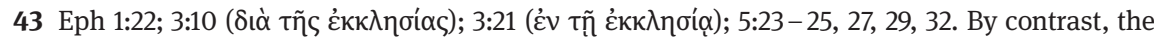
undisputed Pauline letters typically refer to the whole church with a plural form of $\dot{\kappa} \kappa \lambda \eta \eta \sigma i \alpha$, as, for example, in 2 Cor 8:18-19, 23-24; 11:28. See, further, Muddiman, “Church" (see n. 14), 110:

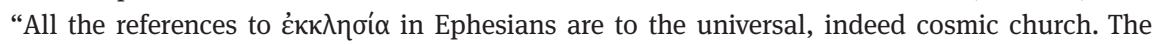
word is not used of the local congregation as it regularly is in Paul." See also Muddiman, Ephesians (see n. 14), 49; Hans Hübner, An Philemon, An die Kolosser, An die Epheser (HNT 12; Tübingen: Mohr Siebeck, 1997), 172-177, 274-276; Gerber, "Epheserbrief” (see n. 42), 321-324.

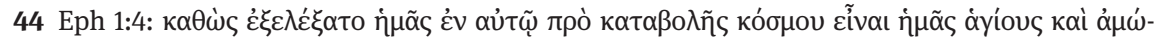

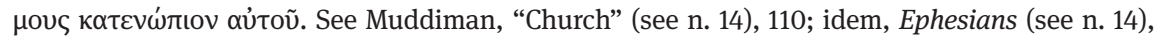
$48-49$.

45 Muddiman, “Church” (see n. 14), 111, is probably correct to conclude about Ephesians that "there is no other book of the New Testament where the emphasis on the transcendent character of the church is so explicit and so marked."

46 See also Muddiman, "Church" (see n. 14), 111. We return to this theme, below. 
In addition, Eph 1:22-23a may be indebted to the Christ-head||church-body imagery that is distinctive to Col 1:18 (cf. 1:24). The author refers to a "head" and to "the church," and immediately thereafter identifies the church as "his [Christ's] body." ${ }^{47}$ In the undisputed letters, the only time that Paul refers to Christ as "head" is in 1 Cor 11:3, where Christ is designated as "the head of every man," 48 not the head of the church or of his own body. The synthesis of applying Christ's headship to all believers who, together, comprise the "body" is first attested in Col 1:18. It thus stands to reason that Eph 1:22-23a is both indebted to earlier Pauline thought and, building on Colossians, two stages beyond from the ecclesiology of the undisputed letters. Later, Eph 4:15 refers to Christ as "the head" without mentioning either the body or the church. ${ }^{49}$

Several aspects of Eph 5:21-33 merit consideration as possible precedents for 2 Clement 14. A metaphorical reference to the ecclesial "body" resurfaces in Eph 5:23: "Man is head of the woman/wife as also Christ is head of the church," and "he [Christ] himself [is] savior of the body."50 Eph 5:23 could well build on the hierarchy of God-Christ-man-woman that is presumed in 1 Cor 11:3. Relative to the undisputed letters, what is new in Eph 5:23 (also 1:22-23a, discussed above) is the identification of Christ's headship over the

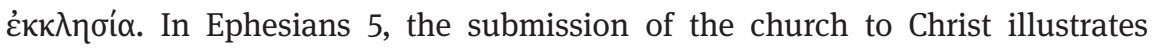
how Christian wives are to relate to their husbands. ${ }^{51}$ Further, Christ's love for the church exemplifies how husbands are to love their wives (Eph 5:25-27). Given that Christ is "savior of the body" ( $\sigma \tilde{\omega} \mu \alpha, 5: 23)$ and that men/husbands will naturally love their own bodies ( $\sigma \omega \dot{\omega} \mu \alpha \tau$, 5:28a-b), each man must likewise love his own wife (5:28c). Ephesians also ascribes to Christ the role of "cherish-

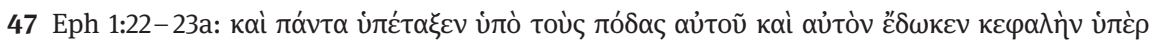

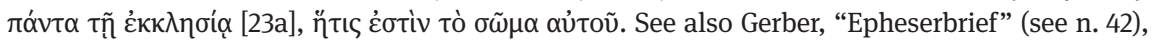
338-340.

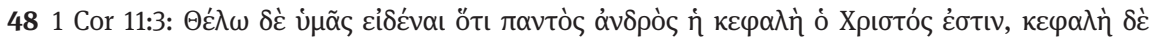

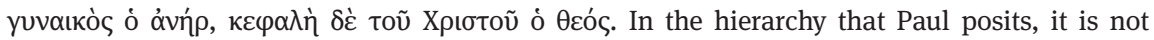
clear whether the apostle would restrict ravtò $\alpha$ ảvoós to designate only Christ-believing men (or husbands), or if he refers to all men (or husbands), whether Jewish, Christian, or polytheist.

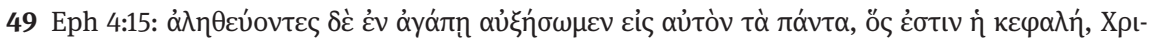
бтóc. In this verse, the metaphor of the "body" in Colossians has been severed from the "head."

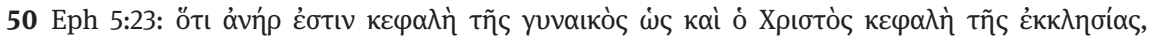

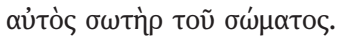

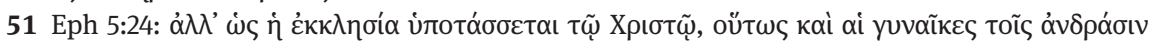

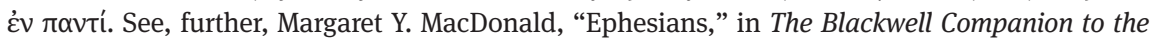
New Testament (ed. David E. Aune; Oxford: Wiley-Blackwell, 2010), 537-550 at 544: "The author of Ephesians has transposed the use of marriage as a metaphor for God's relationship with Israel in the book of Hosea and elsewhere to speak about the relationship between Christ and the church." 
ing” or "comforting" ( $\theta \alpha \dot{\alpha} \lambda \pi \omega)$ the church, which is also the pattern for Christian husbands (5:29). When the author states that "we are limbs/members of his [Christ's] body" (5:30), both the language and the metaphor match the undisputed letters. ${ }^{52}$ Such a teaching about believers as Christ's "limbs" could build directly on 1 Corinthians 12, but presumably not on Colossians (which never uses $\mu \varepsilon^{\prime} \lambda o \varsigma$ to refer to believers as parts of the body). ${ }^{53}$ A citation of Genesis 2 next provides a biblical basis for the application of the Christ-church metaphor to Christian marriage relations (5:31). ${ }^{54}$ Muddiman interprets the use of Gen 2:24 as "an allegory of the union between Christ and the church." 55 Moreover, he holds that "[t]he man and woman in question were not just any Ephesian married couple but the primeval pair, Adam and Eve." ${ }^{56}$ Precisely how in Ephesians 5 the relationship of Christ and the church is to be understood in light of the joining of man and woman "into one flesh" is not entirely clear, however. Also unclear is what the author deems "a great mystery" (5:32), whether the joining "into one flesh" (5:31) or Christ's love and care for the church. ${ }^{57}$ Throughout the pas-

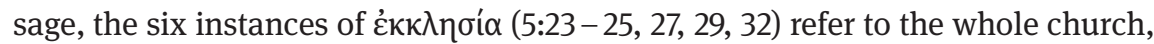
not to a particular congregation or city.

We have suggested that the ecclesiology of Ephesians builds not only on the undisputed letters but also on Colossians. From Paul, the author gleaned an understanding of believers as "limbs" that comprise a single body, as well as the hierarchy presumed in 1 Cor 11:3. As in Col 1:18, Ephesians presents Christ as the "head" of the church and consistently refers to the church in general (cf. Col 1:24). Relative to those earlier Pauline letters, what is new in Ephesians is an interest in male-female relations as informed by Christ's relation to the church (5:21-32); a citation of Genesis 2 on the joining of man and woman "into one flesh" (5:31); and a focus on Christ-believers' moral conduct within the marriage relationship $(5: 28-29,32)$.

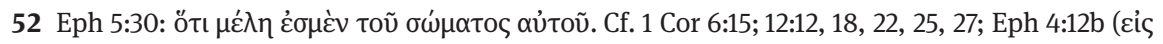

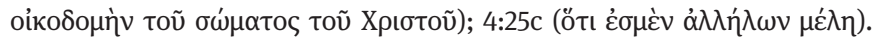

53 Contrast the occurrence of $\mu \varepsilon^{\prime} \lambda \eta$ in Col 3:5 referring to believers' earthly "parts" or "limbs" but without any reference to those limbs comprising a single body.

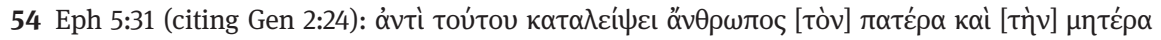

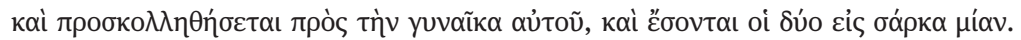

55 Muddiman, “Church” (see n. 14), 111; see also idem, Ephesians (see n. 14), 269-270.

56 Muddiman, “Church” (see n. 14), 112.

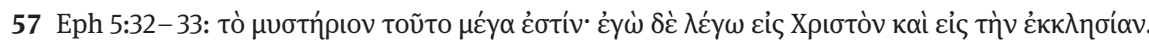

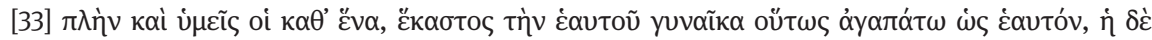

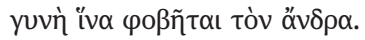




\subsection{Summation and Refinement of the Research Question}

One thing this overview shows is that the terminology of Pauline ecclesiology was by no means fixed but was, on the contrary, adaptable to particular situations and open to embellishments. To the Christ-congregations in Corinth and Rome, Paul employs the body metaphor but has no need for it in other letters. In Colossians (also Ephesians), the body now has a head, and in Ephesians the relationship of Christ to the church exemplifies marital love and conduct. Given the fluidity of the terminology and the malleability of the tradition, an attempt to discern a "pure" Pauline tradition in contrast to either "early Catholic" or "gnostic" variations would likely prove elusive. ${ }^{58}$

Furthermore, the ecclesiological reflections that we have surveyed in the undisputed letters, Colossians, and Ephesians do not straightforwardly anticipate the presentation of the church in 2 Clement 14. Moreover, the lack of extensive verbal overlap between Second Clement and the Corpus Paulinum would likely make it very difficult to demonstrate literary dependence. Nonetheless, it may be asked whether, subsequent to the writing of First Corinthians, Romans, Colossians, and Ephesians, the language of 2 Clement 14 would more likely have arisen independently of, or under the influence of, one or more Pauline letters. We now shift the focus from ascertaining the use of one or more Pauline letters to probing the possibility of influence on Clement.

\section{4 'Екклпбí in Second Clement}

Possibly the most baffling part of Second Clement is the presentation of Christ

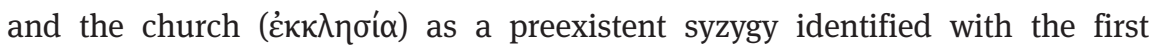
male and female that God created in Genesis 1. In chap. 14, Clement also warns that the flesh will be judged, and in doing so he refers to a primordial time when Christ and the church existed together. In this section we take up key philological and text-critical matters; analyze 2 Clement 14 in its literary and rhetorical context; survey the relevant secondary literature; and consider whether the passage may be indebted to the Corpus Paulinum. Although there are insufficient verbal correspondences to make a compelling case for literary dependence, it is more likely than not that Clement's references to the "church"

58 See also Muddiman, "Church" (see n. 14), 112: "But it would be wrong to think of this development of Paul's teaching [about the church; cf. ibid., 110 -111] as the distortion of an originally functional, low ecclesiology. Rather, the author of Ephesians is intent on exposing and articulating the deeper roots in Jewish apocalyptic of Paul's thought on the church.” 
as Christ's "body" and to "male" and "female" in Genesis 1 are informed, whether directly or indirectly, by Ephesians.

\subsection{Text, Translation, and Notes}

Formidable text-critical, philological, and semantic difficulties present themselves in 2 Clement 14. At times, the original text can be difficult to determine. The best manuscript, Codex Alexandrinus, breaks off in 12:5a. Consequently, for the remainder of the writing, scholars try to make sense of the other Greek witness, Codex Hierosolymitanus (C), which is later and occasionally unreliable, and the Syriac translation (S), which may at times be clumsily correcting an unrecoverable Vorlage. We offer a reconstructed text, a translation, and notes.

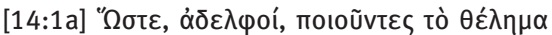

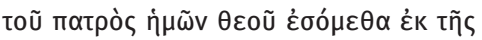

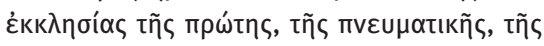

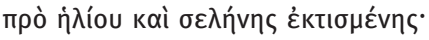

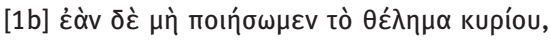

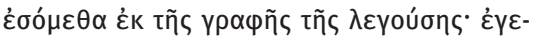

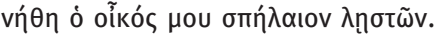

[14:1a] As a result, brothers, if we are doing ${ }^{59}$ the will of our Father [and] God, we shall belong to the first church, ${ }^{60}$ the spiritual one, which was created before the sun and moon. [1b] But if we do not do the Lord's will, we shall belong to [those of whom] the Scripture says, ${ }^{61}$ "My house has become a den of robbers." 22

59 Construing, with Wilhelm Pratscher, Der zweite Clemensbrief (KAV 3; Göttingen: Vanden-

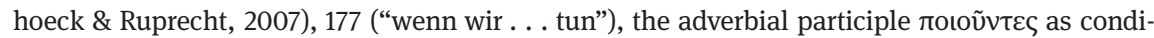

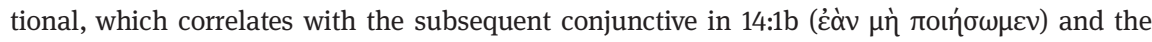
context of 13:3-4 (whether believers show love to each other and their enemies). Additionally, the future $\varepsilon \sigma o$ ó $\mu \varepsilon \alpha$ in 14:1a makes the best sense if the participle is conditional, in addition to matching the apodosis in 14:1b.

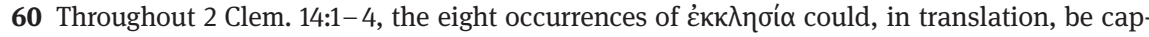

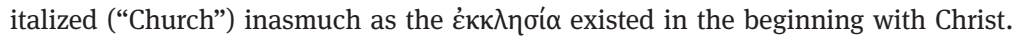

61 Lit. "we will belong to the Scripture which says.” See Joseph B. Lightfoot, The Apostolic Fathers (London: Macmillan, 1885-1890, reprinted Peabody, MA: Hendrickson, 1989), I/2:244, "of those persons described in the Scripture." Similarly Pratscher, Clemensbrief (see n. 59), 177, "von denen die Schrift sagt," whose translation aptly preserves the parallelism of genitive phrases in

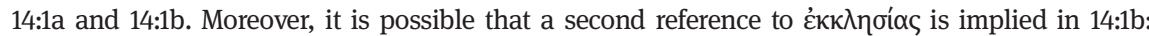
there is the (authentic) church, and a fake one described as a "den of robbers." The following "church of life" may furthermore mean that this other, in 14:1b, is a church/assembly of death. As a result, Clement may call up a judgment scene, such as the scene highlighted in 17:3-7. 62 See Jer 7:11; cf. Matt 21:13||Mark 11:17||Luke 19:46. Tuckett, 2 Clement (see n. 15), 245, argues for Clement's "direct use of the text of Jeremiah itself" without use of any of the Synoptic Gospels. Likewise Andreas Lindemann, Die Clemensbriefe (Die Apostolischen Väter 1; HNT 17; Tübingen: Mohr, 1992), 241. 


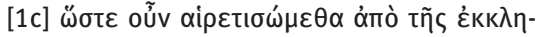

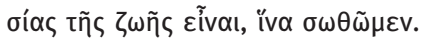

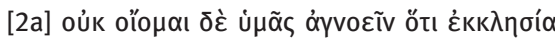

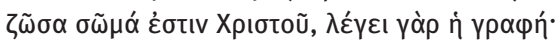

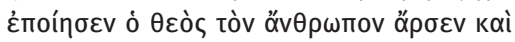
$\theta \tilde{\eta} \lambda u^{*}$

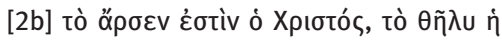

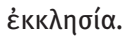

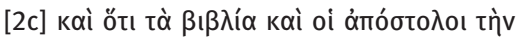

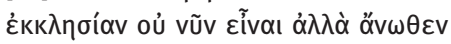

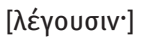

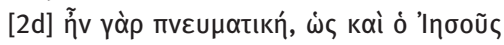

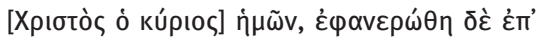

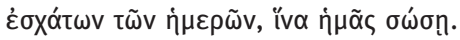

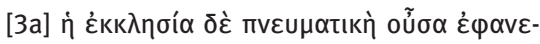
 [1c] As a result, let us choose to belong to the church of life, in order that we may be saved. [2a] I do not suppose that you are ignorant of the fact the living church is the body of Christ, for the Scripture says, "God made the person [as something] masculine and feminine."

[2b] What is "masculine" is Christ, [and] what is "feminine" [is] the church.

[2c] [You know] also that ${ }^{63}$ the books ${ }^{64}$ and the apostles [state] ${ }^{65}$ that the church exists not [only] now but [also] from the beginning. [2d] For she was spiritual, as was also our [Lord] Jesus [Christ], ${ }^{66}$ and he[?] ${ }^{67}$ was revealed in the last days, in order that he[?] might save us.

[3a] And the church, being spiritual, was revealed in the flesh of Christ,

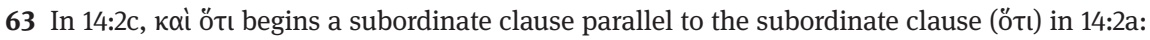

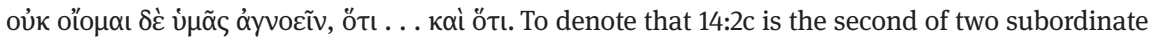
clauses, we supply in 14:2c "[You know]" and translate kaí as "also.” My thanks to Michael Öberg (Uppsala) for this suggestion.

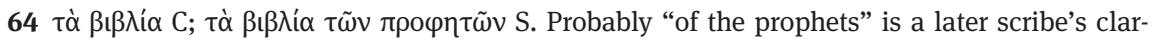
ification, pointing to biblical witnesses that support Clement's contention. Michael W. Holmes (The Apostolic Fathers [3rd ed.; Grand Rapids: Baker Academic, 2007]) omits $\tau \tilde{\omega} v \pi \rho \circ \varphi \eta \tau \tilde{\nu}$. Tuckett (2 Clement [see n. 15]) retains $\tau \tilde{\omega} \nu ~ \pi \rho о \varphi \eta \tau \tilde{\omega} v$ within brackets. Pratscher (Clemensbrief [see n. 59], 177, 182) adopts the longer reading without brackets. Similarly Rudolf Knopf (Die Lehre der zwölf Apostel. Die zwei Clemensbriefe [vol. 1 of Die apostolischen Väter; HNT Ergänzungs-Band; Tübingen: Mohr Siebeck, 1920], 174); Klaus Wengst, Didache (Apostellehre), Barnabasbrief, Zweiter Klemensbrief, Schrift an Diognet. Eingeleitet, herausgegeben, übertragen und erläutert (Schriften des Urchristentums 2; Darmstadt: Wissenschaftliche Buchgesellschaft, 1984), $256-257$.

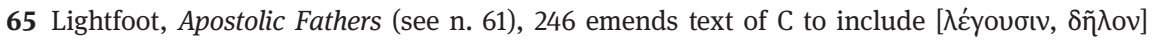

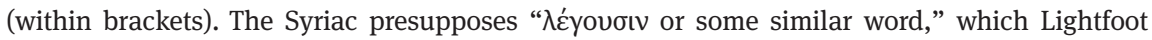
(ibid., 245) views as "an arbitrary correction" but, somewhat confusingly, as nonetheless necessary to make sense of the corrupt Greek text. Tuckett adopts the reading of $\mathrm{S}$ but inserts $\lambda \varepsilon^{\prime}$ you

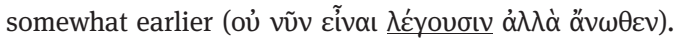

66 Tuckett has the longer reading (without brackets) presupposed by the Syriac and Holmes the shorter reading of C. Pratscher's translation (Clemensbrief [see n. 59], 177) presupposes the longer reading.

67 The five occurrences of $\dot{\varepsilon} \kappa \kappa \lambda \eta \sigma i \alpha$ in 2 Clem. 14:1a-2c could suggest that, in 14:2d, the implied

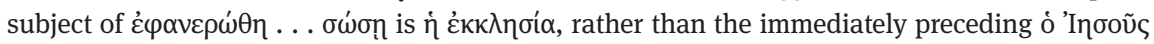

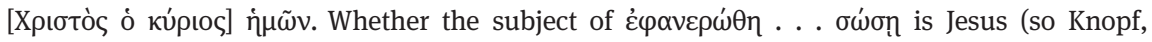
Wengst, Lindemann, Pratscher) or the church (so Holmes and, tentatively, Tuckett), which part of the preexistent syzegy it is that "saves" could, for Clement, be significant soteriologically. See, further, Pratscher, Clemensbrief (see n. 59), 183; Tuckett, 2 Clement (see n. 15), 254-255. 


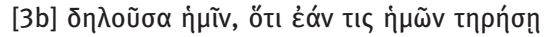

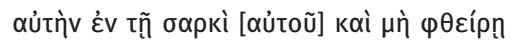

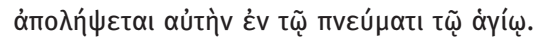

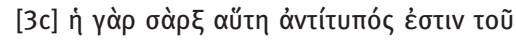

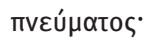

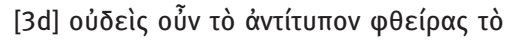
$\alpha u ̉ \theta \varepsilon v \tau t \kappa o ̀ v ~ \mu \varepsilon \tau \alpha \lambda \eta ́ \mid \psi \varepsilon \tau \alpha$.

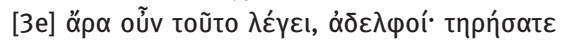

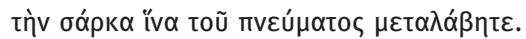

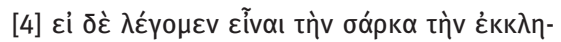

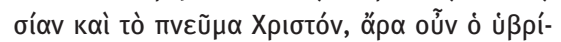

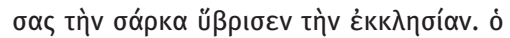

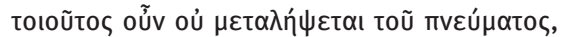

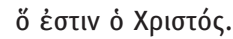

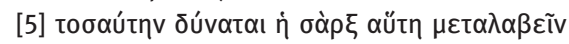

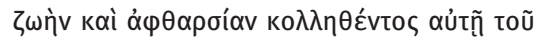

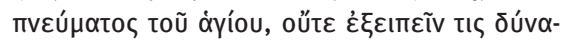

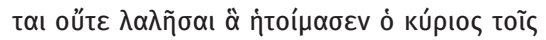

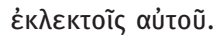

[3b] since he shows us that if any of us guards her in the ${ }^{68}$ flesh and does not corrupt [her], ${ }^{69}$ he [or she] will receive ${ }^{70}$ her in the Holy Spirit. [3c] For this flesh is a copy of the Spirit.

[3d] Therefore nobody, after corrupting the copy, will come to share $\mathrm{in}^{71}$ the original.

[3e] He therefore means this, brothers: guard the flesh, in order that you may have a share in the Spirit.

[4] For if we say that the flesh is the church and the Spirit is Christ, the one who mistreated the flesh has thus ${ }^{72}$ mistreated the church. As a result, such a person will not have a share in the Spirit, which is Christ. [5] This flesh is able to share in such [great] life and immortality, if the Holy Spirit is attached to it [the flesh]..$^{73}$ No person can proclaim or say what the Lord has prepared for his chosen ones.

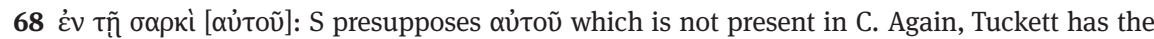
longer reading (without brackets) and Holmes the shorter (without aủ̃oṽ). Since the original

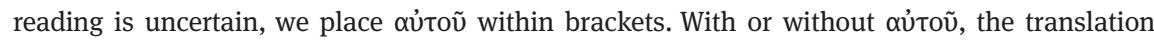
could be the same, since the definite article $\tau \tilde{\eta}$ designates what belongs to $\tau$ เ $\dot{\eta} \mu \tilde{\omega} \nu$ and what is, correspondingly, "his or hers."

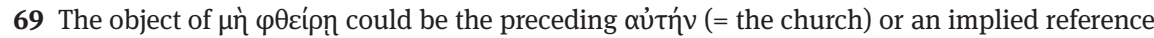

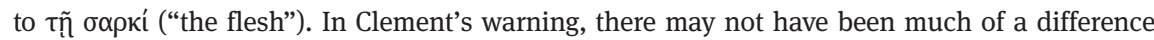
between corrupting the church (which existed "in the flesh") and corrupting one's own flesh.

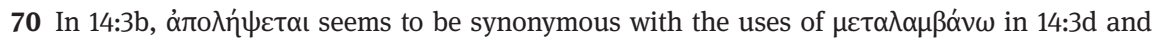
14:5, where this verb (unusually) takes an accusative direct object. Cf. occurrences of $\mu \varepsilon \tau \alpha \lambda \alpha \mu-$ $\beta$ óv $\omega$ with a genitive object in 14:3e and 14:4.

71 This is the first of four occurrences of $\mu \varepsilon \tau \alpha \lambda \alpha \mu \beta \alpha$ v $\omega \omega$ in 14:3d-5. Here, a genitive direct object

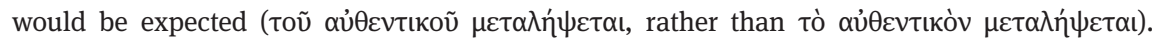

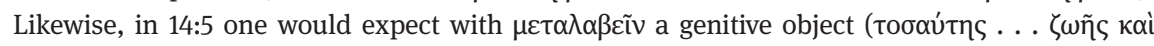

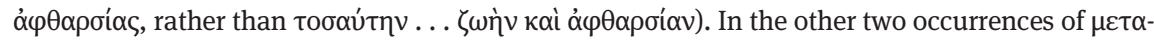

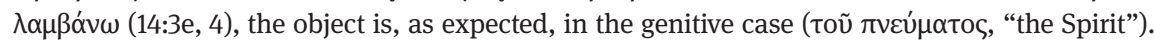

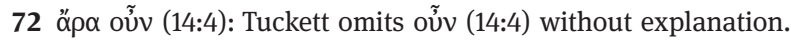

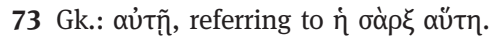




\subsection{Analysis of 2 Clement 14}

Without providing any argument or indicating any polemical context, Clement posits the existence of "the first church, the spiritual one ( $\pi v \varepsilon v \mu \alpha \tau$ t $\eta$ '), which was created before the sun and moon" (14:1a). That "first church" seems to be equivalent to "the church of life" (14:1c), which is also "the body of Christ"

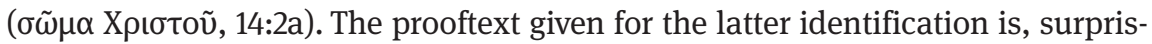
ingly enough, Gen 1:27, concerning when "God made the human being [as something] masculine and feminine." Perhaps the mention of a "body" that existed in the beginning (14:1-2a) brought to Clement's mind the first oै $v \theta \rho \omega \pi$ ऽ in Genesis 1. In any case, it is hard to imagine that an ancient listener would have anticipated Clement's interpretation, "What is male is Christ, [and] what is female [is] the church" (14:2b). Perhaps in an attempt to temper the surprise of some hearers, Clement assures that the prior existence, or preexistence, of the church together with Christ is based on vague but credible authorities - "the books ${ }^{74}$ and the apostles" (14:2c). In the exposition that follows, the basic binary male/female based on Gen 1:27 extends to the other binaries of flesh/spirit (14:3-5) and copy/original $(14: 3 c-d)$. These pairs are necessarily united, and opposed not with each other but with corruption.

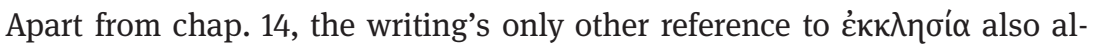
ludes to her earlier existence in the image of the barren woman who cries out in Isaiah 54, where Clement finds a reference to a previously "barren" church:

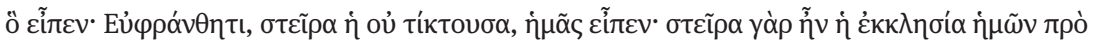

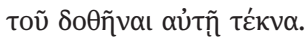

Now what he said, "Rejoice, O barren woman, who bears no children," he spoke in regard to us, for our church was barren before children were given to it. (2 Clem. 2:1c)

In 2:1-3, what Clement means by a childless church is difficult to ascertain. ${ }^{75}$ When 2:1 and 14:1 are read together, it becomes plausible that Clement conceives of the church's previous existence as spirit, of her current existence as flesh, and of her anticipated existence as spirit. The three phases of the church's spiritflesh-spirit existence are analogous to the presentation in 9:1-5 of Christ's existence as spirit, then flesh, and again as spirit. In that earlier passage, Clement

74 See above (n. 64): we adopt the shorter reading of $\tau \dot{\alpha} \beta ı \beta \lambda^{\prime} \alpha$ (C), rather than $\tau \dot{\alpha} \beta ı \beta \lambda^{\prime} \alpha \tau \tilde{\omega} v$ $\pi \rho о \varphi \eta \tau \tilde{\omega} v$ presupposed by the Syriac.

75 On the problem of distinguishing between views reflected in what Second Clement cites, on the one hand, and the views of the author himself, on the other hand, see Kelhoffer, "Prooftexter” (see n. 7), esp. 273-275. 
bases the warning that the flesh will be raised and judged on the premise that

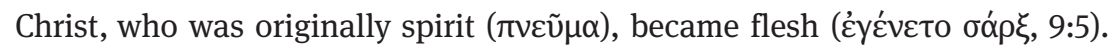

Notably, Clement does not claim that by the time Christ had "become flesh" (9:5), Christ and the childless, preexistent church had already been separated. He seems to indicate the opposite when claiming in 14:3a that "the Church, being spiritual, was revealed in the flesh of Christ."76 Such reasoning apparently holds that, at the time of the incarnation, Christ and the church were somehow still conjoined. Although Clement never mentions the death of Jesus, he clearly envisions a Jesus who suffered much for the church. ${ }^{77}$ Perhaps, then, Clement conceives that the Christ-church syzygy remained intact either at the beginning of time or after the incarnation. If Clement presupposes the death of Jesus, the division between the two could have taken place at that time, after which children could be given to the church (cf. 2:1e). Christ would thereafter be understood as spirit, whereas the church, with her children, has continued to exist as flesh and, according to 14:2a, as Jesus's "body" (= flesh?). Such a view would be consistent with the inference that 14:3b anticipates a return to spiritual existence for those believers who have guarded the church in the flesh. ${ }^{78}$

In Clement's somewhat obscure reflections, a clear and familiar moral tone pervades, highlighting the importance of believers' behavior: whether one does God's will determines a future affiliation with either "the first church" or a "den of robbers" (14:1a-b). Likewise, it is imperative to guard the church "in the flesh" in order to receive her "in the spirit" (14:3b). When Clement reflects that "the flesh is the church and the spirit is Christ" (14:4a), he seems to refer to the differentiated states of their current existence. Christ has been both spirit and flesh and is now spirit, whereas the church was spirit with Christ in the beginning, and is now flesh through the existence of her "children" (cf. 2:1). The conduct of those children in the flesh will determine whether the children will, like Christ himself, regain existence as spirit. However peculiar, these christological and ecclesiological reflections are conspicuously not polemical and require neither Pauline nor anti-Gnostic categories to be understood. ${ }^{79}$ Christ's spirit-flesh-spirit existence is

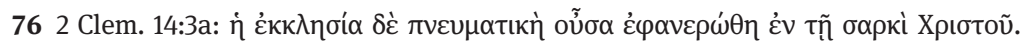

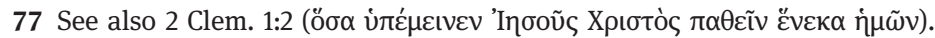

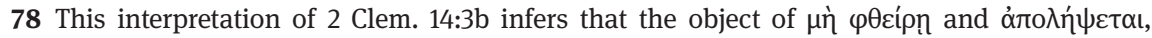

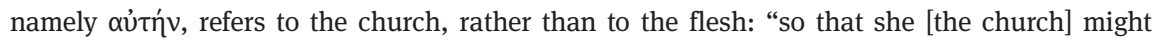

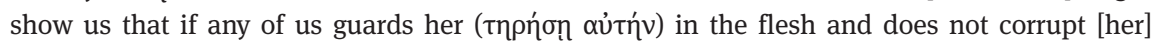

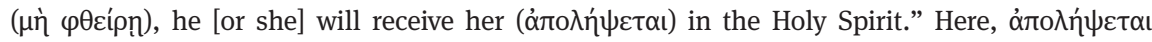
seems to be synonymous with the uses of $\mu \varepsilon \tau \alpha \lambda \alpha \mu \beta \alpha$ v $\omega \omega$ in 14:3d and 14:5.

79 Against Pratscher, Clemensbrief (see n. 59), 178, 184-185, 186, 188, who finds the closest parallels to 14:1-5 “in der valentinianischen Gnosis” (184). Likewise Karl Paul Donfried, The Setting of 
the pattern for the church's spirit-flesh-(future) spirit existence. By implication, Clement does not envision Jesus as having a fleshly resurrected body. The hope for Christians' eventual passage from flesh to spirit is grounded in Christ's transformation (although a resurrection or an ascension is never mentioned), and that transformation for Christians depends on their moral conduct.

Our interpretation of chap. 14 in light of 2:1 and 9:1-5 can be brought to bear on the Jesus logion that is cited in 12:2b, 6b: the coming of the kingdom could be understood as when Christ (the male) is reunited with the church (the female), and that reunification hinges upon whether believers "are doing these things" (12:6a) - that is, truth-telling and cultivating androgynous thinking (12:3-5). Likewise, in 14:1-5 the crux of Clement's apprehension concerns believers' moral conduct - whether they will sufficiently guard the flesh and thereby attain an existence as spirit that Christ himself has attained.

\subsection{The Status Quaestionis: Did Ephesians Influence Second Clement?}

In 1905, a committee of the Oxford Society for Historical Theology, which included J. Vernon Bartlet, James Drummond, and Kirsopp Lake, came to a negative conclusion about the influence of the Pauline letters, including Ephesians, on Second Clement. ${ }^{80}$ Since that time, most scholars have tended to concur with the committee's assessment. In what follows, we suggest some reasons for questioning that consensus.

An exception to the scholarly consensus is Holt Graham, who unreservedly affirms the influence of Ephesians on 2 Clement 14: "The thought of [14:]1 can be derived easily from Ephesians 1:3 ff (so Lightfoot p. 243), but is easily adapted to Gnostic purposes. [...] Again in [14:]2 the thought of Ephesians has been extended." ${ }^{81}$ In regard to the interpretation of Gen 1:27 in 14:2 ("God made the person

Second Clement in Early Christianity (NovTSup 38; Leiden: Brill, 1974), 160 -166, esp. 166; Wengst, Zweiter Klemensbrief (see n. 64), 275, 277-278; Rüdiger Warns, "Untersuchungen zum 2. Clemens-Brief” (Th.D. diss., Philipps-Universität Marburg, 1989), 211-212, 217-230, 589-590. More cautiously, Lindemann, Clemensbriefe (see n. 62), 241, suggests that Clement "maybe" (möglicherweise) writes polemically against "the Gnostics."

80 A Committee of the Oxford Society for Historical Theology, The New Testament in the Apostolic Fathers (Oxford: Clarendon, 1905), esp. 53, 125-127.

81 Graham, Second Clement (see n. 18), 125. In regard to 2 Clem. 14:2, Graham refers the reader to Hans Windisch, "Das Christentum des 2. Clemensbriefes," in Harnack-Ehrung. Beiträge zur Kirchengeschichte ihrem Lehrer Adolf von Harnack zu seinem 70. Geburtstage (7. Mai 1921) dargebracht von einer Reihe seiner Schüler (Leipzig: Hinrichs, 1921), 119-134 at 130. 
[as something] masculine and feminine"), Graham posits a direct "exegesis" of Ephesians 5. ${ }^{82}$ Graham concludes about the interpretations of Pauline materials in 2 Clement 14 that "[i]t would appear that the author of 2 Clement lives in an environment where imaginative exegesis like that of the Gnostics is already flourishing." ${ }^{83}$ In sum, Graham finds an explanation for much in 2 Clement 14 by positing Clement's exegesis of Ephesians and other Pauline letters, and the particular type of exegesis is understood in light of how "the Gnostics" supposedly interpreted esteemed traditions.

Strictly speaking, Graham's point about gnostic exegesis as "imaginative" is not erroneous. What would be dubious in contemporary scholarship would be to single out gnostic exegesis, as if Paul's letters and early Christian Gospels, not to mention any number of ancient Jewish and early Christian pseudepigrapha, could not be equally creative and acontextual in their interpretations. Such a demarcation between gnostic and other ancient writings is arguably grounded more in modern dogma or ideology than in critical theory. Gnostic interpretations could indeed be acontextual and even incoherent - but arguably not more so than other roughly contemporaneous Jewish, Christian, and even Neoplatonic writings. As Williams points out, a particularly gnostic "inverse exegesis" or "protest exegesis" probably never existed, except as a polemical label for the unpalatable interpretations of "others." 84

In 1979, Andreas Lindemann came to a more nuanced conclusion on the question of Ephesians's influence: “Der ursprünglich paulinische Charakter der in 2 Clem 14 enthaltenen Ekklesiologie ist also kaum zu bestreiten; er ist aber dem Vf nicht bewußt." 85 Lindemann's two contentions merit comment, since it would be possible to concur with either, neither, or both of them:

82 Graham, Second Clement (see n. 18), 126: "It is difficult not to suppose that most of this is exegesis of Ephesians 5:23-33, where Christ's Church is referred to as his body (5:23) or his flesh (5:29), and the story of Adam and Eve is referred to Christ and his Church (5:31-32)." Graham continues noting parallels to 2 Cor 11:2-3 (on not corrupting the church) and to Gal 4:25-26 (on Jerusalem above) before mentioning another parallel to Ephesians: "For revelation through the Church, see Ephesians 3:10” (ibid.). Similarly, Knopf, Clemensbriefe (see n. 64), 173174 draws the closest comparisons between 2 Clem. 14:1-5 and Ephesians.

83 Graham, Second Clement (see n. 18), 126.

84 See, above, on Williams, Rethinking “Gnosticism" (see n. 19), 54-79, esp. 60-62. See also Karen L. King, What Is Gnosticism? (Cambridge: Harvard University; London: Belknap, 2003), 151, 169, 201-208. In addition, I am indebted to Petter Spjut (Uppsala) for insights in this paragraph.

85 Andreas Lindemann, Paulus im ältesten Christentum. Das Bild des Apostels und die Rezeption der paulinischen Theologie in der frühchristlichen Literatur bis Marcion (BHT 58; Tübingen: Mohr, 1979), 267. See also idem, Clemensbriefe (see n. 62), 241, who identifies in 2 Clem. 14:2a after ötı a 
1. The ecclesiology of 2 Clement 14 was originally, and distinctively, Pauline.

2. Clement was unaware that his ecclesiology was distinctively Pauline.

In these two claims, Lindemann intriguingly explains that the passage's ecclesiology can be understood in terms of an indirect and, to Clement himself, unknown Pauline influence. The Wirkungsgeschichte of Ephesians or another Pauline letter could be seen at work here, yet without a later author knowing what original concept or writing is being worked on or developed.

In a commendable survey of the reception of Paul in Second Clement, Andrew Gregory concludes, "there is now a widespread consensus that although 'Clement' employed imagery used also by Paul, nevertheless the evidence suggests that at no point did he make conscious and deliberate reference either to Paul or to his writings." ${ }^{86}$ Of particular relevance to the present inquiry is Gregory's conclusion that "the strongest evidence" for Second Clement's use of NT epistolary literature "is found with respect to Ephesians and Hebrews." 87 In regard to the possible influence of Ephesians, Gregory finds "[t]he most significant parallel” to be between 2 Clem. 14:2 and Eph 1:22; 5:23. ${ }^{88}$ Gregory also indicates, but does not discuss, the possible relevance of Eph 1:4, on God's choice of "us" prior to the world's beginning. ${ }^{89}$

In a sometimes overlooked essay, John Muddiman devotes several pages to five arguments that Ephesians influenced Second Clement: ${ }^{90}$

\footnotetext{
"Zitat [...] der sich traditionsgeschichtlich paulinischer bzw. deuteropaulinischer Ekklesiologie verdankt."

86 Gregory and Tuckett, "2 Clement and the Writings" (see n. 16), 278-289 at 279. See, further, Christopher Tuckett, "2 Clement and Paul," in Paulus - Werk und Wirkung (ed. Paul-Gerhard Klumbies and David S. du Toit; FS Andreas Lindemann; Tübingen: Mohr Siebeck, 2013), 529545.

87 Gregory, "2 Clement and the Writings" (see n. 16), 292 continues, "but these parallels [to Ephesians and Hebrews], though tantalizing, are insufficient to raise dependence to the level of probability, rather than mere possibility." Pratscher, Clemensbrief (see n. 59), 184 n. 45 concurs with Gregory (against Muddiman) on this point. On Hebrews, compare 2 Clem. 11:6 with Heb 10:23 and 12:1 and see Gregory, "2 Clement and the Writings," 289-291.

88 Gregory, "2 Clement and the Writings" (see n. 16), 286, referring to 2 Clem. 14:2 yet citing 14:2a-c without 14:2d, in which the occurrence of $\sigma \omega ́ \sigma n$ (cf. $\sigma \omega \tau \eta \dot{\rho}$, Eph 5:23) could be relevant.

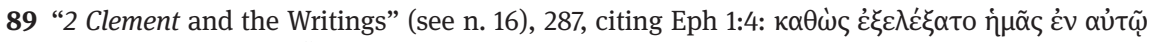

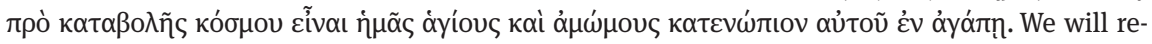
turn to Eph 1:4, below.
}

90 Muddiman, “Church” (see n. 14), 113-116. 


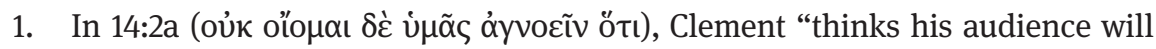
be familiar with" such "ideas" about the church "from elsewhere."91

2. "[T]here is an explicit reference not just to scripture [...] but also to the apos-

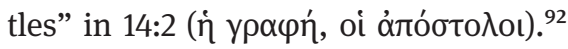

3. 2 Clem. 14:1 and 14:2 should be interpreted together, and the citation of Gen 1:27 (in 14:2) should be seen as an allegory on the preceding reference to "the first church" (14:1a). ${ }^{93}$

4. Clement's reference to "a den of robbers" (14:1b) alludes to Jesus's "cleansing of the Temple" and may thereby "imply [...] that the first church [...] is God's true temple and house of prayer." 94

5. Earlier, in chap. 12, Clement's disposing "of the literal connotation of the male-female contrast" clears the way "for a purely allegorical interpretation of the Genesis allusion in chapter 14."95 Further, the presentation of male and female in chap. 12 illustrates "very much how a sexual ascetic like our preacher would have read the household code of Eph. 5."96

Below, we will suggest that although none of these five arguments is compelling Muddiman's proposed methodology and general conclusion are sound.

On the basis of those arguments, Muddiman concludes that "the number of echoes we have noted" to Ephesians in Second Clement "is sufficient to increase considerably the probability of his [Clement's] having read it [Ephesians]." ${ }^{97}$ Notably, Muddiman does not try to demonstrate literary dependence but nonetheless argues for the use and influence of Ephesians on Clement. Since Clement uses a variety of sources and "is not, after all, writing a commentary on Ephesians [...] exact similarity in wording" between the two writings "may not in itself be a satisfactory criterion for establishing a literary relation."98

91 Muddiman, "Church" (see n. 14), 114.

92 Muddiman, “Church” (see n. 14), 114-115.

93 Muddiman, “Church” (see n. 14), 115.

94 Muddiman, “Church” (see n. 14), 115.

95 Muddiman, "Church" (see n. 14), 115-116 at 115.

96 Muddiman, "Church" (see n. 14), 116.

97 Muddiman, “Church” (see n. 14), 116. See also David Lincicum, "Learning Scripture in the School of Paul. From Ephesians to Justin,” in The Early Reception of Paul (ed. Kenneth Liljeström; Helsinki: Finnish Exegetical Society, 2011), 148-170. Following a brief discussion of possible influences of Paul's letters on Second Clement, Lincicum proposes that the possibility that Clement had "direct recourse to the apostle's writings [...] merits further consideration" (162163).

98 Muddiman, “Church” (see n. 14), 116, 121. 
Although we concur with both Muddiman's conclusion and, in particular, with his method of considering similarities that are not exact verbal matches, his five arguments are not particularly compelling. Each of them merits a brief comment. Muddiman's first observation is inconclusive inasmuch as none of us has access to what Clement actually "thinks." Clement may refer to an actual, mutually accepted authority or he may be rhetorically basing his position upon a contrived authority. Muddiman's second observation is somewhat stronger but is also unconvincing, since although "the apostles" could well include Ephesians as a Pauline letter, the reference to "the apostles" grounds the ideas within a broad stream of tradition that may, or may not, include Ephesians or other letters in the Corpus Paulinum.

In support of his third argument, Muddiman finds analogies in Second Temple Jewish wisdom and apocalyptic writings. ${ }^{99}$ His valid point about the preexistence of Wisdom and Israel in such writings does not, however, lead conclusively in the direction of Ephesians as a source for Clement's understanding of the church's preexistence. Muddiman's fourth argument is rather far fetched: Clement's reference to "a den of robbers" (14:1) does not necessarily call to mind Jesus's cleansing of the temple, as reported in an earlier Gospel. ${ }^{100}$ Even if one were to grant that premise, it is not clear that 2 Clem. 14:1-2 would be allegorically interpreting Jesus's temple cleansing in terms of a clean, or pure, church. Fifth, Muddiman's interpretation of 2 Clement 12 is questionable: that passage does not "dispose of the literal sexual connotation of the male-female contrast." ${ }^{101}$ Nor is it accurate to characterize Clement as "a sexual ascetic."102

Five weak arguments do not make a strong case for Muddiman's thesis that, although "the textual evidence [...] is inconclusive," the "conceptual similarities" between Ephesians and Second Clement "raise the likelihood of dependence to a higher level of probability." ${ }^{03}$ Nonetheless, Muddiman is to be commended for exploring both the extent of the writings' verbal overlap and other "conceptual

99 Muddiman, "Church" (see n. 14), 115: "The themes of the pre-existence of Wisdom in Jewish sapiential literature and the pre-existence of Israel in Jewish apocalyptic are here being reapplied to the church.”

100 See Pratscher, Clemensbrief (see n. 59), 179-180; Tuckett, 2 Clement (see n. 15), 245, 249250: "There is [...] no evidence to support any suggestion that 2 Clement has been influenced by the text of the gospels here" (245).

101 So Muddiman, “Church” (see n. 14), 115.

102 Contra Muddiman, "Church" (see n. 14), 116. On these comments about 2 Clement 12, see Kelhoffer, "Eschatology" (see n. 4).

103 Muddiman, "Church" (see n. 14), 109. 
similarities" that could place the writings in the same milieu and, possibly, in contact with each other.

Most recently, Paul Foster offers a fresh and thorough examination of the evidence, arguing for the absence of Paul in Second Clement, which could be due to the "mundane explanation" that in this rather brief exhortation Clement had no occasion to draw on specifically Pauline material. ${ }^{104}$ For the most part, Foster concurs with Gregory's negative assessment of possible Pauline parallels to Second Clement. According to Foster, "the Pauline writing that is most likely to have some literary affinity with 2 Clement is Ephesians." 105 Even in that case, Foster holds that "the different ways in which that imagery" about male and female in relation to Christ and the church "is deployed and the different ecclesiologies behind the metaphor strongly tell against direct literary dependence."106 In reaching that conclusion, Foster indicates that he disagrees with Muddiman but does not respond to Muddiman's suggestion of criteria in addition to verbal overlap for ascertaining the possible influence of one text on another. ${ }^{107}$

In a wide-ranging survey such as Foster's, the brevity of interaction with Muddiman is understandable. Nonetheless, a possible limitation in the criteria that Foster applies may be noted: for Foster (and Gregory), the same imagery must be used in the same way if literary dependence is to be discerned. That criterion does not fit with what we know about Clement's other uses of esteemed traditions. Even when Clement cites gospel materials that bear the marks of Matthean or Lukan redaction, his citations can be quite free, and his interpretations rather creative relative to the meanings posited in the Synoptics. ${ }^{108}$ Those free citations and creative interpretations do not discount the importance of the identification of Matthean and Lukan redactional markers in the citations. Rather, they attest to an author who was not only deeply indebted to authenticating his views by using earlier written traditions but also free to adapt earlier traditions to suit his own purposes. It can therefore be asked whether, for second-century

104 Paul Foster, "The Absence of Paul in 2 Clement," in The Apostolic Fathers and Paul (ed. Todd D. Still and David E. Wilhite; Pauline and Patristic Scholars in Debate 2; London: Bloomsbury, 2017), 61-78 at 78. By contrast, another recent volume on early Pauline reception, Paul and the Second Century (ed. Michael F. Bird and Joseph R. Dodson; LNTS 412; London: T\&T Clark, 2011), examines neither First Clement nor Second Clement.

105 Foster, “Absence” (see n. 104), 69. See also Gregory, "2 Clement and the Writings" (see n. 16), 286; idem, "Afterword: Some Reflections on Methods and Approaches," in The Apostolic Fathers and Paul (see n. 104), 233-245 at 238 (apparently concurring with Foster).

106 Foster, “Absence” (see n. 104), 70.

107 Foster, “Absence” (see n. 104), 70 n. 30 (“contra J. B. Muddiman” [see n. 14]).

108 See Kelhoffer, "Prooftexter” (see n. 7); idem, "Eschatology” (see n. 4); Tuckett, 2 Clement (see n. 15), 34-38. 
Christian authors such as Clement, an anachronistic criterion of unaltered borrowing has been applied. ${ }^{109}$ Applying such a strict criterion could regrettably overlook the free use of source materials characteristic of Second Clement and, indeed, of most second-century Christian literature. ${ }^{110}$

\subsection{The Likelihood that Ephesians 5 Influenced 2 Clement 14}

Gregory and Foster are probably correct to conclude that the parallels between

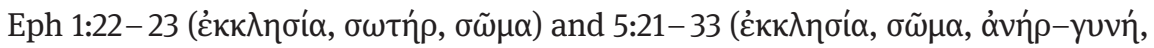

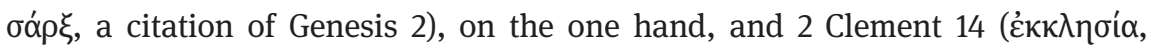
$\sigma \tilde{\omega} \mu \alpha$, $\tilde{\alpha} \rho \sigma \eta \nu-\theta \tilde{\eta} \lambda \nu \varsigma, \sigma \omega \dot{\omega} \zeta \omega, \sigma \alpha \dot{\alpha} \xi$, a citation of Genesis 1), on the other hand, do not, by themselves, allow for a definitive conclusion about literary dependence. Nor do those parts of Ephesians offer a plausible rationale for why Clement would present the church as a woman who existed in the beginning with Christ. Moreover, the main themes in Ephesians 5 about the headship of Christ and, by extension, about the headship of áví over yuví play no role in 2 Clement 14. None of these concepts rules out any possible use of Ephesians, but neither do they yield conclusive proof for inferring that Clement used or was influenced by Ephesians.

As a possible way forward, we return to Graham's largely unsubstantiated yet, nonetheless, possibly correct - thesis that "The thought of [2 Clem. 14:]1 can

109 Tuckett, 2 Clement (see n. 15), 248 n. 15 points out two differences between Ephesians and Second Clement but does not address whether one writing may have impacted the other. Similarly, the valid observation that "some of what is said" in 2 Clement 14 "about the church seems to go beyond Ephesians in a significant way" (ibid., 251) is not a compelling rationale for rejecting that Ephesians may have influenced Clement. Similarly, Tuckett discounts the possibility

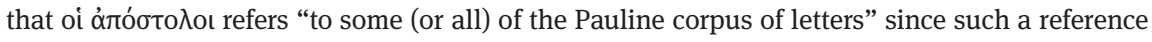
to Paul "would then be unique within 2 Clement" (ibid., 253). Similarly, Lindemann, Clemensbriefe (see n. 62), 241-242, 243 highlights differences with Ephesians 5 as sufficient grounds for dismissing a literary connection.

110 In the same volume as Foster's contribution, David L. Eastman, "Paul as Martyr in the Apostolic Fathers," in The Apostolic Fathers and Paul (see n. 104), 1-19 at 17-18, comes to a remarkably different conclusion about the relation of Second Clement to the Corpus Paulinum. Eastman finds in 2 Clem. 5:1-4 "imagery taken especially from 2 Tim 4:6-8" and also from 1 Cor 9:24-25. His very brief discussion and the absence of reflection on criteria for ascertaining a direct literary relationship render the comparisons that he draws uncompelling. Further, Eastman's response (p. 18 n. 62) to Gregory's 2005 essay (see n. 16) does not actually weaken Gregory's conclusions in regard to those passages. 
be derived easily from Ephesians 1:3ff."111 We will consider the possible relevance of Eph 1:3-5a for 2 Clem. 14:1-2c.

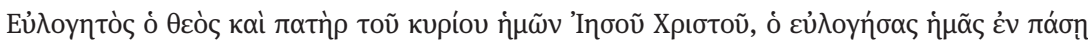

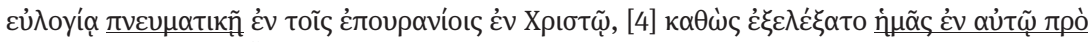

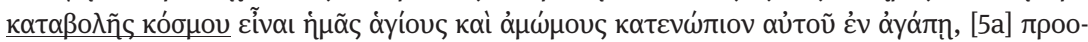

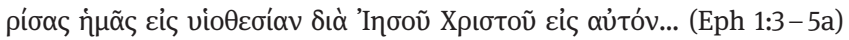

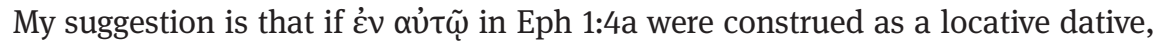
the inference could follow that "we" (i் $\mu \tilde{\alpha} \varsigma)$ existed already "in" Christ "prior to

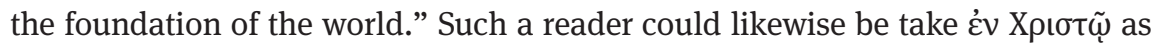
locative in the previous participial phrase (1:3b), which would arguably be sup-

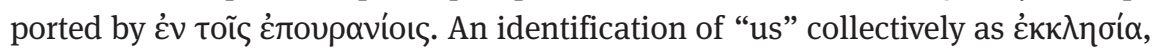
although consistent with Pauline thought, would not be a distinctively Pauline formulation.

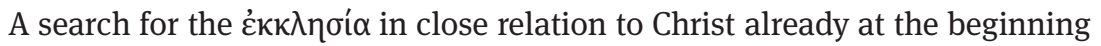
of time could then ensue. This possibility about Clement's use of Ephesians is not an assertion about the original meaning of Eph 1:4. Whatever that deuteroPauline author may have meant there could be beside the point. Important soteriological differences between the two writings may also be noted: whereas Ephesians assumes that the saints will be "holy and blameless" (cf. Eph 1:3), Clement is deeply concerned about the readiness of his Christ-believing addressees to face the final judgment and, ultimately, be saved (esp. 2 Clem. 17:3-7). Furthermore, the "Paul" of Ephesians presents believers as both chosen in Christ before the foundation of the world (1:3-5a) and already raised and seated with Christ in the heavenly realms (2:6). ${ }^{112}$ According to that apostolically ascribed letter, their salvation is not only predestined but already accomplished. Such an eschatology of an already realized resurrection may have been unpalatable, or even objectionable, to the author of Second Clement for two reasons. First, Clement shows no interest in the resurrection of Christ or in a past or future resurrection of believers. Second, an already completed resurrection may well have conflicted with Clement's many warnings (including in 14:1, 3-4) that future salvation is contingent upon good conduct prior to the final judgment. ${ }^{113}$ These acute differences between the two writings' soteriologies supply a motiva-

111 Graham, Second Clement (see n. 18), 125 (discussed above).

112 See, above, on Muddiman, “Church" (see n. 14), 111.

113 See James A. Kelhoffer, "Reciprocity as Salvation. Christ as Salvific Patron and the Corresponding 'Payback' Expected of Christ's Earthly Clients according to the Second Letter of Clement,” NTS 59 (2013): 433-456, esp. 447-454. 
tion for why an author like Clement would both have used and modified elements of Ephesians's ecclesiology. The explanation that Clement uses a teaching like, or the same as, Ephesians and simultaneously writes in partial opposition to such a work's soteriology would correlate with the marked similarities and differences between the two texts. ${ }^{114}$ The contested standing of Paul's legacy in the second century could be relevant here: it may not be advantageous to the author such as Clement to confront the "Paul" of Ephesians directly, or even to mention him.

Our proposal about the possible influence of Eph 1:3-5a, or of some similar tradition, is analogous to Augustine's interpretation of Rom 5:12 in the Vulgate: ${ }^{115}$

\begin{tabular}{|c|c|}
\hline Rom 5:12, $N A^{28}$ & Rom 5:12, Vulgata \\
\hline 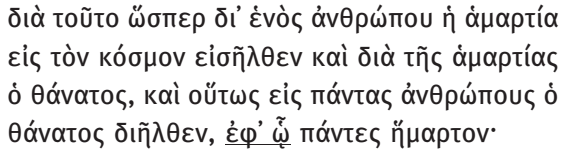 & $\begin{array}{l}\text { propterea sicut per unum hominem in hunc } \\
\text { mundum peccatum intravit et per peccatum } \\
\text { mors et ita in omnes homines mors pertransiit } \\
\text { in quo omnes peccaverunt }\end{array}$ \\
\hline
\end{tabular}

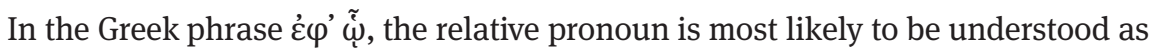

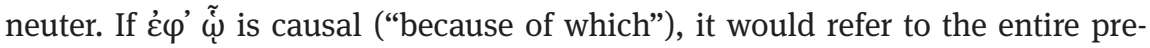

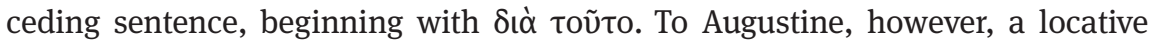
ablative construal of in quo seemed most likely, meaning that all humanity had sinned at the time of their earlier existence "inside of" (in) Adam.

If a similar reading strategy were applied to Eph 1:3-5a, the insight could follow that when God "chose us in him [Christ] before the foundation of the world," all believers were in some way already "in" Christ prior to the creation

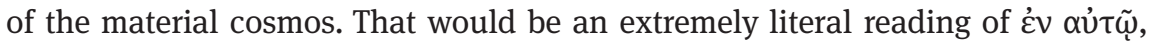
taking the phrase as locative (= inside of Christ) rather than, for example, instrumental (= with, or through, Christ).

114 In Eph 1:22, there is a stark contrast between the spatial metaphors of what is below Christ's feet and Christ's place at the top, or "head," of the body. Neither of those spatial metaphors is taken up in 2 Clement 14. In Eph 5:23, the metaphor of headship is extended from Christ's position of sovereignty (cf. Eph 1:22) to that of "a man" (áví $\rho$ a husband?) in relation to "the woman" ( $\tau \tilde{\Upsilon} \zeta$ yuvaıkó $=$ the wife?). By contrast, Second Clement shows no interest either in Christ's supreme position (pace Eph 1:22) or in the need to conform to patriarchal norms

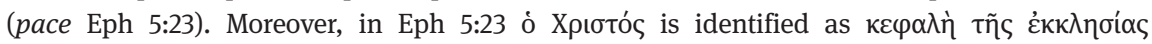

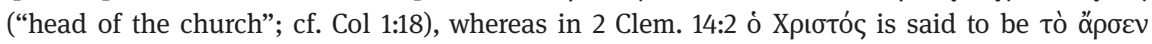
("that which is masculine").

115 On this point, see Augustine, On the Merits and Forgiveness of Sins and on Infant Baptism and Mark Reasoner, Romans in Full Circle. A History of Interpretation (Louisville: Westminster John Knox, 2005), 46-47. 
What we would not yet have would be an explanation of why the church is identified as the woman, and Christ as the man of Gen 1:27. It may suffice to note

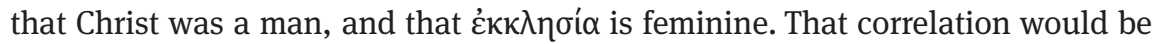
suggestive but not, by itself, a satisfying explanation. Besides in 2 Clement 14, the only other reference to $\varepsilon \kappa \kappa \lambda \eta \sigma i ́ \alpha$ in Second Clement is 2:1c. ${ }^{116}$ There, the "barren woman" of Isa 54:1 is identified as $\dot{\eta} \dot{\varepsilon} \kappa \kappa \lambda \eta \sigma i \alpha \dot{\eta} \mu \tilde{\omega} \nu$ : "Now what he said, 'Rejoice, $\mathrm{O}$ barren woman, who bears no children,' he spoke in regard to us, for our church was barren before children were given to it." If one identifies the church as a woman and if one searches for confirmation that she existed in the beginning with, or "in," Christ, Gen 1:27 may not seem like such a far-fetched verse to explore. After all, the "Paul" of Ephesians 5 had quoted from Gen 2:24 about Adam and Eve when teaching about Christ and the church, and Gen 1:27 belongs to the general prelapsarian timeframe of Gen 2:24.

Admittedly, this hypothetical exegetical exercise does not prove the use of Ephesians in Second Clement. What it does suggest is that the scriptural interpretation and ecclesiological inferences drawn in 2 Clem. 14:1-2 do not require analogies to 'gnostic' speculation about creation myths in order to be understood. Nor need one suppose a willful distortion of a sacred text (aka inverse exegesis). The supplying of puzzle pieces like Eph 1:3-5a and 5:21-33 would also account for how Clement could attribute such a teaching to one or more written and

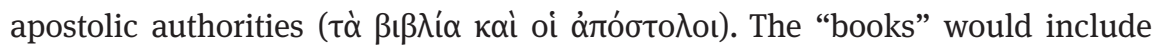
the early chapters of Genesis, and "the apostles" would include the "Paul" of Ephesians.

\section{Conclusion}

In this essay we have concurred with Gregory, Foster, and other scholars that a positive case for a direct literary relationship between Ephesians and Second Clement probably cannot be made. We have also agreed with Muddiman that, when weighing the relative probability of a literary relationship, similarities between two writings in addition to exact verbal agreement can, and arguably should, be taken into consideration. One reason for the need of such an additional criterion is the nature of our source material. Nowadays scholars are in general agreement that we need criteria that do not assume the chronological priority, or an ubiquitously ascribed authority, of the writings that eventually be-

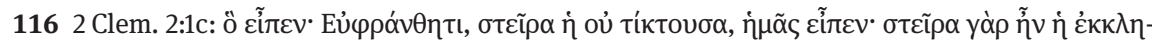

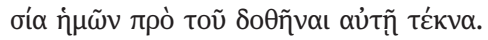


came canonical. Numerous early Christian authors who cited from and interpreted esteemed traditions did not assume the role of scribes entrusted with faithfully copying and preserving sacred Scripture. ${ }^{117}$ Further, with the notable exceptions of Heracleon's Commentary on John and Hippolytus's Commentary on Daniel, ${ }^{118}$ early Christian authors did not attempt to write commentaries on entire biblical passages or books. As a result, it may be prudent for future scholarship to assess which criteria are most apt for evaluating the complex ways that early Christian authors could both make use of, and improvise on, earlier written traditions.

In the case of the preexistent church in 2 Clement 14, we have suggested a number of reasons to infer that either Ephesians or a very similar apostolically ascribed writing informed Clement's ecclesiology:

- The metaphor of the body of Christ is distinctively Pauline, occurring in both undisputed and deutero-Pauline letters. Only at 2 Clem. 14:2 does it appear in the Apostolic Fathers.

- The "church" is first identified as Christ's "body" in Colossians. That identification is made also in Ephesians and Second Clement and is distinctive to those three writings.

- In the second century, a well-educated author could have based the ecclesiological musings of 2 Clement 14 using Neoplatonic hermeneutics on any number of sacred texts. Clement claims that his teaching about the church is based on "the books and the apostles" (12:2c) with which the addressees are already familiar. It is thus reasonable to ask what apostolically ascribed writings, such as Colossians and Ephesians, may have been available to Clement and his audience.

- The ecclesiology of Ephesians is distinctive within the Corpus Paulinum:

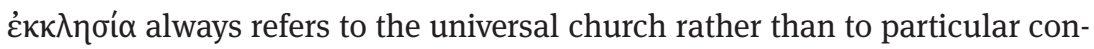
gregations or gatherings in a particular city, as is typical in the undisputed Pauline letters.

117 As Bart D. Ehrman, The Orthodox Corruption of Scripture. The Effect of Early Christological Controversies on the Text of the New Testament (2nd ed.; Oxford: Oxford University, 2011) lucidly argues, even later scribes could make theologically motivated emendations to biblical manuscripts.

118 On the former writing, see Ansgar Wucherpfennig, Heracleon Philologus. Gnostische Johannesexegese im zweiten Jahrhundert (WUNT 142; Tübingen: Mohr Siebeck, 2002) and the Uppsala dissertation in preparation by Carl Johan Berglund, “Quarreling Colleagues. Heracleon's Exegesis of the Gospel of John and the Critical Response by Origen of Alexandria” (2019). On the latter, see Katharina Bracht, Hippolyts Schrift In Danielem. Kommunikative Strategien eines frühchristlichen Kommentars (STAC 85; Tübingen: Mohr Siebeck, 2014); eadem, Hippolyt von Rom, Danielkommentar. Eingeleitet, übersetzt und kommentiert (BGrL 80; Stuttgart: Anton Hiersemann, 2016). 
- According to Eph 1:3-5a, the elect were chosen and predestined to be adopted "prior to the foundation of the world." Supposing that primordial point in time when God "blessed us in Christ" (Eph 1:3) could easily suggest the notion that the church existed with Christ in the beginning.

- Ephesians 5 discusses at length the place of "male" and "female" in analogous relation to Christ and the church.

- The citation of Gen 2:24 in Ephesians 5 takes readers and hearers back to the time of Adam and Eve.

These similarities have led us to form the following research question: subsequent to the writing of First Corinthians, Romans, Colossians, and Ephesians, would the language of 2 Clement 14 have more likely arisen independently of, or under the influence of, one or more Pauline letters?

Given the particular ecclesiological language and the developments that can be traced within the Pauline letters, it is more plausible to infer that Ephesians or some very similar writing informed 2 Clement 14 than to infer that Clement would have made such statements about the church wholly independently of a writing like Ephesians. If our inference is compelling, it may be worthwhile to consider the possibility of influence from additional Pauline letters on Second Clement, since the earliest attestations to Ephesians are as part of a collection of Pauline letters. It could also be helpful to weigh how Platonic and even Neoplatonic hermeneutics may have affected the reception of Pauline letters in late antiquity. ${ }^{119}$

If Clement is interpreting Ephesians, he may also be correcting its soteriology: instead of a predestined elect who have already been raised and seated with Christ (Eph 1:3-5a; 2:6), he warns about the dangers of corrupting the flesh (2 Clem. 14:3-5), with the hope that his flock will be prepared for the final judgment (17:3-7). For Clement, only those who keep the flesh pure will have assurance of belonging to "the first, spiritual church" (14:1) and, as part of that church, of being reunited with Christ, with whom the church existed in the beginning (14:2).

119 Curiously, Pratscher, Clemensbrief (see n. 59), 186 seems to equate "das platonische" with what is "gnostic." Contrast Knopf, Clemensbriefe (see n. 64), 175, who, without referring to "Gnosticism," suggests how 2 Clem. 14:3 "platonizes” (platonisiert). 